\title{
A roadmap for amphibious drilling at the Campi Flegrei caldera: insights from a MagellanPlus workshop
}

\author{
Marco Sacchi ${ }^{1}$, Giuseppe De Natale ${ }^{2}$, Volkhard Spiess ${ }^{3}$, Lena Steinmann ${ }^{3}$, Valerio Acocella ${ }^{4}$, \\ Marta Corradino $^{5}$, Shanaka de Silva ${ }^{6}$, Alessandro Fedele ${ }^{2}$, Lorenzo Fedele ${ }^{7}$, Nobuo Geshi ${ }^{8}$, \\ Christopher Kilburn $^{9}$, Donatella Insinga ${ }^{1}$, Maria-José Jurado ${ }^{10}$, Flavia Molisso ${ }^{1}$, Paola Petrosino ${ }^{7}$, \\ Salvatore Passaro $^{1}$, Fabrizio Pepe ${ }^{5}$, Sabina Porfido ${ }^{11,2}$, Claudio Scarpati ${ }^{7}$, Hans-Ulrich Schmincke ${ }^{12}$, \\ Renato Somma $^{2}$, Mari Sumita ${ }^{12}$, Stella Tamburrino ${ }^{1}$, Claudia Troise ${ }^{2}$, Mattia Vallefuoco ${ }^{1}$, and \\ Guido Ventura ${ }^{13}$ \\ ${ }^{1}$ Istituto di Scienze Marine (ISMAR), Consiglio Nazionale delle Ricerche (CNR), \\ Calata Porta di Massa, 80133 Naples, Italy \\ ${ }^{2}$ Istituto Nazionale di Geofisica e Vulcanologia (INGV), Sezione di Napoli, \\ Via Diocleziano, 328, 80124 Naples, Italy \\ ${ }^{3}$ Faculty of Geosciences, University of Bremen, Klagenfurter Str., 28359 Bremen, Germany \\ ${ }^{4}$ Dipartimento di Scienze Geologiche, Università degli Studi Roma Tre, \\ Largo S.L. Murialdo, 1, 00146 Rome, Italy \\ ${ }^{5}$ Dipartimento di Scienze della Terra e del Mare (DiSTeM), Università degli Studi di Palermo, \\ Via Archirafi, 22, 90123 Palermo, Italy \\ ${ }^{6}$ College of Earth, Ocean, and Atmospheric Sciences, Oregon State University, Corvallis, OR 97331, USA \\ ${ }^{7}$ Dipartimento di Scienze della Terra, dell'Ambiente e delle Risorse (DiSTAR), \\ Università degli Studi di Napoli Federico II, Via Cinthia, 21, 80126 Naples, Italy \\ ${ }^{8}$ Geological Survey of Japan, National Institute of Advanced Industrial Science and Technology, \\ AIST Tsukuba Central 7, 1-1-1 Higashi, Tsukuba, Ibaraki 305-8567, Japan \\ ${ }^{9}$ UCL Hazard Centre, Department of Earth Sciences, University College London, \\ Gower Street, London WC1E 6BT, UK \\ ${ }^{10}$ Institut de Ciències de la Terra Jaume Almera, Consejo Superior de Investigaciones Científicas (CSIC), \\ C/Lluís Solé i Sabarís s/n, 08028 Barcelona, Spain \\ ${ }^{11}$ Istituto di Scienze dell'Alimentazione (ISA), Consiglio Nazionale delle Ricerche (CNR), \\ Via Roma, 64, 83100 Avellino, Italy \\ ${ }^{12}$ GEOMAR Helmholtz Centre for Ocean Research Kiel, Wischhofstr. 1-3, 24148 Kiel, Germany \\ ${ }^{13}$ Istituto Nazionale di Geofisica e Vulcanologia (INGV), Via di Vigna Murata, 605, 00143 Rome, Italy \\ Correspondence: Marco Sacchi (marco.sacchi@cnr.it)
}

Received: 20 March 2019 - Revised: 14 September 2019 - Accepted: 26 September 2019 - Published: 2 December 2019

Abstract. Large calderas are among the Earth's major volcanic features. They are associated with large magma reservoirs and elevated geothermal gradients. Caldera-forming eruptions result from the withdrawal and collapse of the magma chambers and produce large-volume pyroclastic deposits and later-stage deformation related to post-caldera resurgence and volcanism. Unrest episodes are not always followed by an eruption; however, every eruption is preceded by unrest.

The Campi Flegrei caldera $(\mathrm{CFc})$, located along the eastern Tyrrhenian coastline in southern Italy, is close to the densely populated area of Naples. It is one of the most dangerous volcanoes on Earth and represents a key example of an active, resurgent caldera. It has been traditionally interpreted as a nested caldera formed by collapses during the $100-200 \mathrm{~km}^{3}$ Campanian Ignimbrite (CI) eruption at $\sim 39 \mathrm{ka}$ and the $40 \mathrm{~km}^{3}$ eruption of the Neapolitan Yellow Tuff (NYT) at $\sim 15 \mathrm{ka}$. Recent studies have suggested that the CI may instead have been fed by a fissure eruption from the Campanian Plain, north of Campi Flegrei. 
A MagellanPlus workshop was held in Naples, Italy, on 25-28 February 2017 to explore the potential of the $\mathrm{CFc}$ as target for an amphibious drilling project within the International Ocean Discovery Program (IODP) and the International Continental Drilling Program (ICDP). It was agreed that Campi Flegrei is an ideal site to investigate the mechanisms of caldera formation and associated post-caldera dynamics and to analyze the still poorly understood interplay between hydrothermal and magmatic processes. A coordinated onshore-offshore drilling strategy has been developed to reconstruct the structure and evolution of Campi Flegrei and to investigate volcanic precursors by examining (a) the succession of volcanic and hydrothermal products and related processes, (b) the inner structure of the caldera resurgence, (c) the physical, chemical, and biological characteristics of the hydrothermal system and offshore sediments, and (d) the geological expression of the phreatic and hydromagmatic eruptions, hydrothermal degassing, sedimentary structures, and other records of these phenomena. The deployment of a multiparametric in situ monitoring system at depth will enable near-real-time tracking of changes in the magma reservoir and hydrothermal system.

\section{Introduction}

Large collapse calderas are associated with climactic explosive volcanic eruptions capable of producing a global catastrophe second only to that from a meteorite impact. On the other hand, many calderas are characterized by hydrothermal systems that represent a source of "clean", geothermal energy production (e.g., Lipman, 2000). Despite numerous scientific and applied studies, the inner structure and the dynamics of caldera systems are still poorly known. In many cases, large calderas also host densely populated urban and agricultural districts. As a consequence, understanding the caldera structure and dynamics has an immediate effect on the assessment of volcanic hazards and associated risk at a local and global scale.

Large calderas are found on all continents and in different geological settings. For example, recent restless examples can be found in New Zealand (Taupo), North America (Crater Lake, Long Valley, Valles, Newberry, and Yellowstone), South America (Laguna de Maule and Cerro Blanco), Asia and Oceania (Toba, Tambora, Krakatau, Rabaul, Toya, Shikotsu, and Kuttara), and Europe (Santorini and Campi Flegrei). Some of these are located close to coastlines and continental shelves, where hydrothermal and groundwater dynamics may partly control the expression of volcanism and the distribution of eruptive products. Deposition of these products occurs in a changing depositional regime with a high average sedimentary supply. Coastal and partly submerged calderas on continental shelves thus contain unique stratigraphic archives of interbedded volcaniclastic and marine deposits with a high potential for preservation.

The Campi Flegrei caldera $(\mathrm{CFc})$, next to Naples in southern Italy, has been the world's most restless, non-erupting caldera for the last 69 years, characterized by episodes of significant ground uplift, enhanced hydrothermal activity, and seismicity. In addition to these short-term episodes (e.g., 1950-1952, 1969-1972, and 1982-1984; De Natale et al., 2006; Del Gaudio et al., 2010; Troiano et al., 2011; Chiodini et al., 2015, 2017; Kilburn et al., 2017; Moretti et al., 2017,
2018), ground subsidence and uplift of several meters has been documented since at least Roman times (e.g., Bellucci et al., 2006; Di Vito et al., 2016). Moreover, as a result of resurgence over the last ca. 12000 years, the central part of the $\mathrm{CFc}$ has undergone a long-term, antiformal uplift of ca. $100 \mathrm{~m}$ that is partly recorded by La Starza marine terrace's present-day elevation (ca. $40 \mathrm{~m}$ above sea level) that emerged ca. 5000 years ago (Di Vito et al., 1999; Sacchi et al., 2014).

The cause of ground uplift episodes and phases occurring at the $\mathrm{CFc}$ (magmatic vs. hydrothermal) is still debated and likely consists of periods of shallow magmatic intrusions accompanied by injections of deep fluids into shallow aquifers (e.g., De Vivo and Lima, 2006; De Natale et al., 2006; Lima et al., 2009; Moretti et al., 2018; Troise et al., 2019). Significant hydrothermal activity is shown on land and in the submerged portion of the caldera by the discharge of hot gases and liquids (Sacchi et al., 2014; Passaro et al., 2016; Chiodini et al., 2017; Steinmann et al., 2018). Since offshore emissions cover an area 4 times larger than the main onshore hydrothermal site around the Solfatara crater (Passaro et al., 2014; Somma et al., 2016; Steinmann et al., 2018), the marine portion of the $\mathrm{CFc}$ may play a substantial role in the recent dynamics of the caldera, representing an underestimated source of degassing and heat flux. The lack of adequate data on offshore fluid emissions prevents a correct estimate of the fluid release and gas and heat flow budget at Campi Flegrei. In addition, while the uppermost $100 \mathrm{~m}$ of the submerged part of the CFc have been intensively studied (D'Argenio et al., 2004; Milia and Torrente, 2007; Sacchi et al., 2009, 2014; Passaro et al., 2016; Steinmann et al., 2016, 2018), the deeper portion remains largely unknown.

Understanding the mechanisms for unrest and eruptions is of primary importance for confident hazard assessment. Data on the deeper, submerged portion of Campi Flegrei are required to constrain forecasts of the type, intensity, and frequency of future magmatic, phreatomagmatic, and hydrothermal eruptions. More than 600000 people are potentially exposed to pyroclastic flows, rising to about 2 million considering the ash fall, also emitted from submerged 
vents (Rossano et al., 2004; Mastrolorenzo et al., 2006, 2008; Tonini et al., 2015; Sandri et al., 2016, 2018). Traditionally, calderas have been analyzed through field studies, monitoring observations, analogue models, and numerical simulations (e.g., Druitt and Sparks, 1984; De Natale et al., 1991, 2001, 2006; Martí et al., 1994, 2008; Gudmundsson et al., 1997; Gudmundsson, 1998; Burov and Guillou-Frottier, 1999; Acocella et al., 2000, 2001, 2004; Martí and Gudmundsson, 2000; Roche et al., 2000; Roche and Druitt, 2001; Folch and Martí, 2004; Lavallée et al., 2004; Geyer et al., 2006; Gregg et al., 2012, 2013). More recently, offshore reflection seismic imaging has emerged as a tool to understand the stratigraphic architecture and shallow structure of collapse-resurgent calderas in continental margins (e.g., Sacchi et al., 2009, 2014; Passaro et al., 2016; Steinmann et al., 2016, 2018). However, only deep drilling can provide conclusive information on the causes and mechanics of unrest and on the state and evolution of the magmatic-hydrothermal system. These data represent a fundamental prerequisite for evaluating the caldera-related hazards (Lowenstern et al., 2017).

\section{Campi Flegrei caldera}

Campi Flegrei is an active caldera belonging to the Neapolitan Volcanic District, which includes the active volcanoes of Vesuvius and Ischia Island. The caldera contains the westernmost districts of Naples as well as the towns of Pozzuoli, Bacoli, Baia, and Quarto and several smaller villages. Half of the $\mathrm{CFc}$ is submerged and forms Pozzuoli Bay (also known as the Gulf of Pozzuoli). This area has represented an active segment of the eastern Tyrrhenian margin since the Late Quaternary (Oldow et al., 1993; Ferranti et al., 1996) and may be considered a natural laboratory for studying the interplay between tectonics and explosive volcanism in the rifted backarc margin of the Tyrrhenian Sea and the Adriatic subduction system below the Apennine fold-and-thrust belt (Fig. 1) (e.g., Milia and Torrente, 1999; Acocella et al., 1999).

The CFc describes a quasi-circular depression approximately $13 \mathrm{~km}$ across. The present-day shape of the caldera has been conventionally interpreted as the result of two large collapses related to the eruptions of the Campanian Ignimbrite (CI, $39 \mathrm{ka}$; Giaccio et al., 2017) and the Neapolitan Yellow Tuff (NYT, 15 ka; Deino et al., 2004) (Fig. 2) with respective volumes of $200 \mathrm{~km}^{3}$ DRE (dense-rock equivalent) (Rolandi et al., 2003) and $40 \mathrm{~km}^{3}$ DRE (Scarpati et al., 1993). Evidence of older ignimbrites has been reported in the Campanian Plain (De Vivo et al., 2001) and in the distal marine archives (e.g., Insinga et al., 2014). The locations of these eruptions remain poorly constrained around Campi Flegrei. As described below, an alternative view now emerging is that the CI was erupted outside Campi Flegrei so that the caldera was formed only by the NYT eruption.
The CI eruption is Europe's largest explosive volcanic event recorded in the last 200000 years. It has been considered a possible cause for the decline of the Neanderthals, thus implying a potential influence on human evolution (Fitzsimmons et al., 2013). The CI deposits are widespread in the Mediterranean, and its ash has been found in the Russian Plain, more than $2500 \mathrm{~km}$ away from the source (Pyle et al., 2006; Giaccio et al., 2008). The CI eruption was followed by the NYT eruption at $15 \mathrm{ka}$ and at least 60 post-caldera eruptions (Di Vito et al., 1999). The most recent eruption occurred in 1538 after a repose of ca. 3000 years. It produced Monte Nuovo and was preceded by a century of uplift (Bellucci et al., 2006; Di Vito et al., 2016). Most recently, noneruptive unrest episodes occurred during 1950-1952, 19691972, and 1982-1984 (Del Gaudio et al., 2010). They have been characterized by ground deformation (with rates up to $100 \mathrm{~cm} \mathrm{yr}^{-1}$ ), shallow, low magnitude earthquakes (about 16000 events with a magnitude up to 4.0 in 1983-1984), and marked geochemical variations in the emitted gases (Berrino et al., 1984; De Natale and Zollo, 1986; Dvorak and Berrino, 1991; De Natale et al., 1991, 1995, 2001; Battaglia et al., 2006; Chiodini et al., 2015; Di Luccio et al., 2015; Moretti et al., 2017, 2018). In fact, the recorded history of non-eruptive ground movements goes back to Roman times as revealed by marine incrustations and mollusks on Roman and medieval buildings (e.g., Bellucci et al., 2006; Troise et al., 2019). Campi Flegrei thus represents the caldera with the longest record of ground movements not immediately followed by eruptions. Uplift began again in 2005 after 20 years of subsidence. It has been characterized by a slow movement of ca. $3 \mathrm{~cm} \mathrm{yr}^{-1}$ and less seismicity but a longer duration than previous uplifts (Troise et al., 2007; Chiodini et al., 2017; Moretti et al., 2018). The long duration of the ongoing unrest has led the Civil Protection Department to declare the first level on its alert scale (yellow), which implies an increase in monitoring activities.

Although the CI eruption has been previously considered as the main caldera-forming event (Rosi and Sbrana, 1987; Orsi et al., 1996), De Vivo et al. (2001) and Rolandi et al. (2003) presented evidence in favor of a fissure eruption to the north of the CFc. Recently, new evidence of buried CI products inside the caldera area at a depth of ca. $400 \mathrm{~m}$ beneath the surface has been found in the pilot borehole of the ICDP (International Continental Drilling Program) Campi Flegrei Deep Drilling Project (CFDDP) (De Natale et al., 2016). The shallow depth and modest thickness of the deposit (less than $200 \mathrm{~m}$ ) raised further questions about a caldera collapse associated with the CI eruption. These and other studies highlight the complexity of the caldera system and, hence, the need for additional in situ information to fully understand the whole framework and evolution of volcanism in Campania. Due to its partly submerged setting, Campi Flegrei represents an ideal site to test the potential of IODP (International Ocean Discovery Program) shallow-water drilling on a volcanic continental margin by a multiplatform drilling pro- 


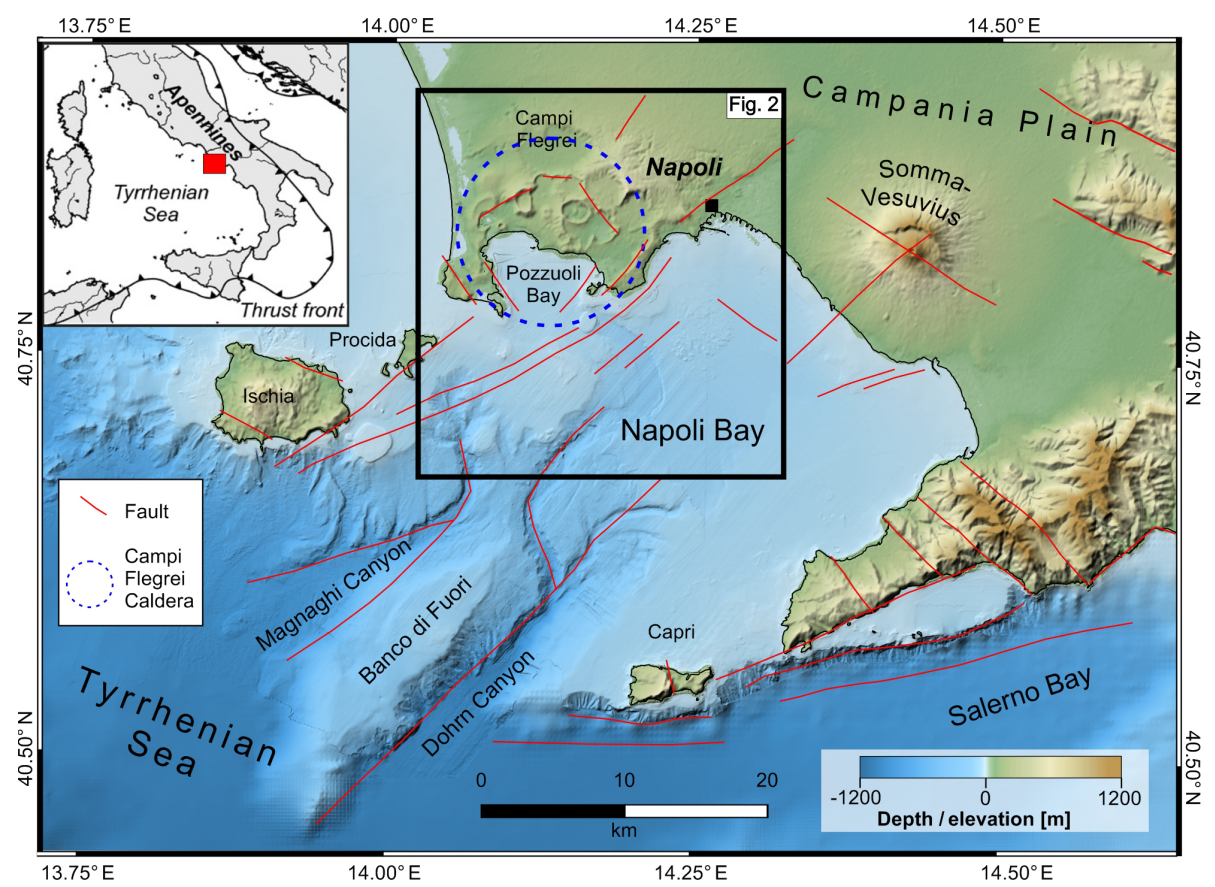

Figure 1. Tectonic sketch map of the Campanian continental margin in SW Italy with the location of the Campanian volcanic zone. Frame of Fig. 2 is also indicated.

gram including a land-sea transect, in the frame of a fully integrated IODP-ICDP Amphibious Drilling Proposal (ADP). The research outcomes derived from Campi Flegrei may also be transferred to similar partly submerged volcanic systems, including the Aira, Kikai, Krakatoa, Maug, Santorini, and Tavui calderas.

\section{The MagellanPlus workshop}

During the MagellanPlus workshop held in Naples on 2528 February 2017, 35 participants from four European countries (Italy, Germany, Spain, and the UK), the USA, and Japan, gathered to discuss the key scientific issues for a coordinated IODP-ICDP proposal dedicated to drilling in the $\mathrm{CF}$. The workshop built upon previous research and networking activities, including (1) a coordinated ICDP and ESF (European Science Foundation) Magellan workshop held on 13-15 November 2006 in Naples; (2) an approved ICDP full proposal (Campi Flegrei Deep Drilling Project CFDDP) in 2006-2008; (3) a submitted IODP pre-proposal (\#671) in 2006-2007 with an indication of resubmission on the basis of an implemented site-survey package; (4) the realization of two pilot holes, a few meters apart, 500 and $200 \mathrm{~m}$ deep, as a preliminary phase to the ICDP deep drilling (the $200 \mathrm{~m}$ hole has been continuously cored by wireline drilling and used to install a borehole seismometer); and (5) the acquisition of new offshore site-survey data (3-D multiscale multichannel and single-channel reflection seismics, multi- beam bathymetry, and gravity core data) between 2008 and 2016 (Fig. 3).

Participants at the MagellanPlus workshop represented a wide range of disciplines, including volcanology, geology, geophysics, geomorphology, petrology, geochemistry, and geochronology, as well as numerical and analogue modeling. The initiative was intended to bring together experts, earlycareer researchers, and other representatives from academia and industry involved in marine and continental research drilling. The aims were to (1) provide a global perspective on the potential and challenges of scientific drilling at active calderas, (2) discuss drilling issues on volcanic continental margin settings, (3) illustrate the new site-survey data, and (4) define drilling objectives for reconstructing stratigraphic events associated with the caldera's evolution and the interaction between magmatism and hydrothermal activity in coastal marine settings.

Participants were asked to contribute to scientific debates on volcanism and associated hazards over coastal areas and identify problems that can be addressed by coordinated marine and continental drillings, with reference to the $\mathrm{CFc}$ as a representative case study. The workshop program addressed data integration, the building of a scientific rationale for drilling strategies, and scientific partnering through a multidisciplinary approach, by linking geology, geophysics, volcanology, petrology, microbiology, and geotechnology. The event is among the first efforts to assess scientific themes directly related to volcanic hazards in highly populated coastal 


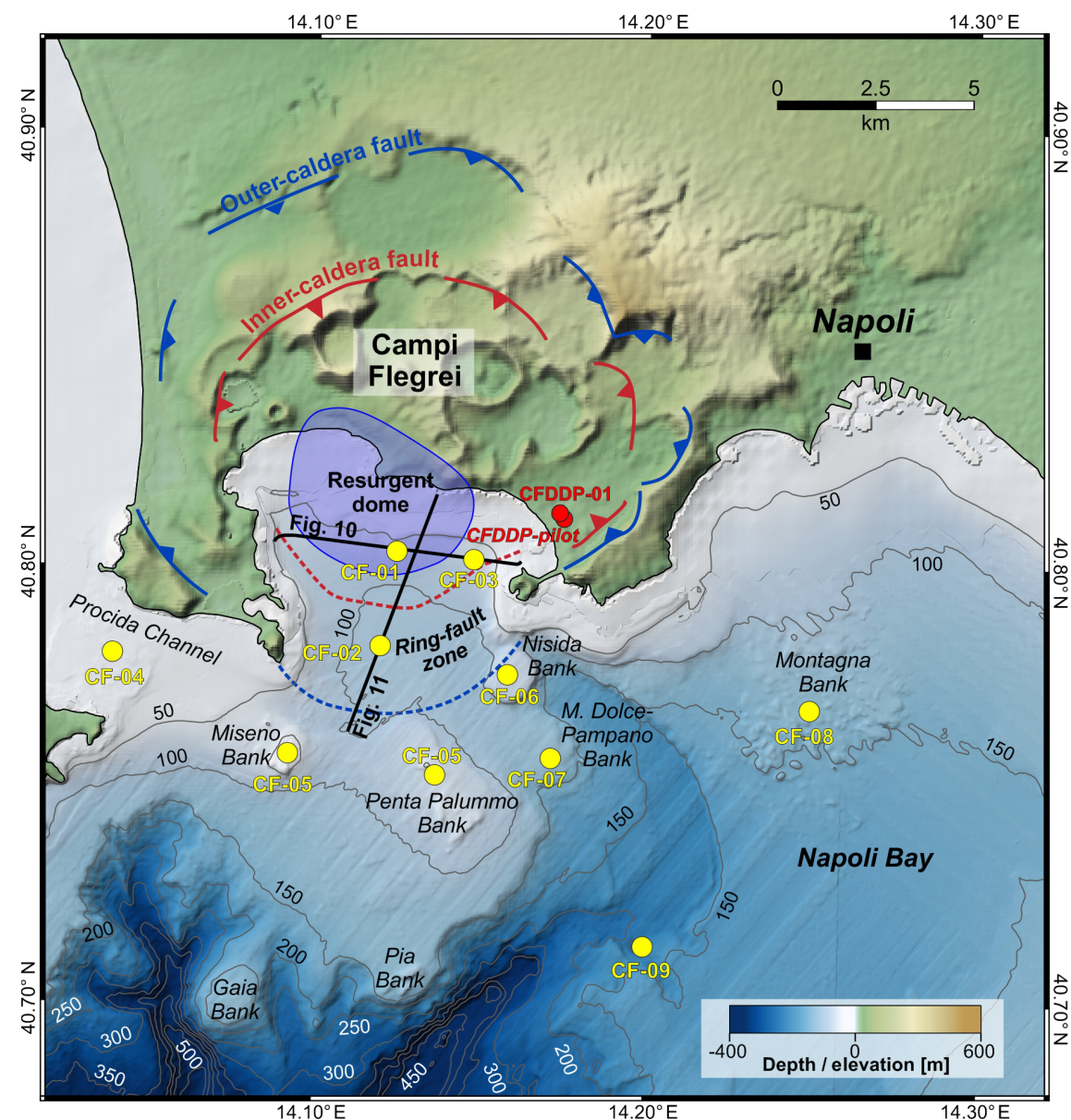

Figure 2. Digital Terrain Model (DTM) of the Campi Flegrei caldera (CFc) showing the structural border(s) and the offshore ring-faultresurgent-dome system associated with the eruption of the Neapolitan Yellow Tuff (NYT) $(\sim 15 \mathrm{ka})$, along with the most prominent subaerial and submerged volcanic morphologies of Napoli Bay. Location of seismic reflection profiles illustrated in Figs. 10 and 11 is also indicated.

areas within the context of fully integrated IODP-ICDP drilling research.

Fundamental questions were discussed on a wide range of topics, such as the mechanisms and timing of caldera formation and resurgence, ignimbrite deposition environments, magma transfer processes, and explosive volcanic activity in submarine and coastal settings, volcano-tectonic coupling, the dynamics and energy budget of onshore and offshore hydrothermal (geothermal) systems, subaerial vs. submarine volcanic unrest, and monitoring. Participants identified the following key questions and objectives that, which shall be addressed by the Amphibious Drilling Proposal:

- Interaction between magmatic and hydrothermal processes. This will be investigated regarding shallow crustal levels, the mechanism of submarine degassing and hot fluid discharge and their contribution to deformation, and recent unrest. What are the source, dynamics, and consequences of the hydrothermal activity in the marine portion of Campi Flegrei, and how are they related to unrest? Does the structural framework of the
$\mathrm{CFc}$ exert control on the ascent of fluids and magma? Can microbial communities help in tracing hydrothermal fluid paths and defining thermodynamic environments and facies at depth?

- Stratigraphy and structures of the CFc. This will be investigated within the half-graben system of the Bay of Naples. This investigation includes recovering a representative stratigraphic record of the caldera fill and borders, down to the upper structural levels of the caldera floor and reconstructing the distribution of the CI (and older ignimbritic) deposits across the Bay.

- Kinematic reconstruction of caldera collapse structure and resurgence. This investigation includes reconstructing the pattern, timing, and rates of deformation involving the various structural components of the $\mathrm{CFc}$ system.

- Eruptive history of the CFc. When was the onset of volcanic activity, and what was the driving mechanism, 


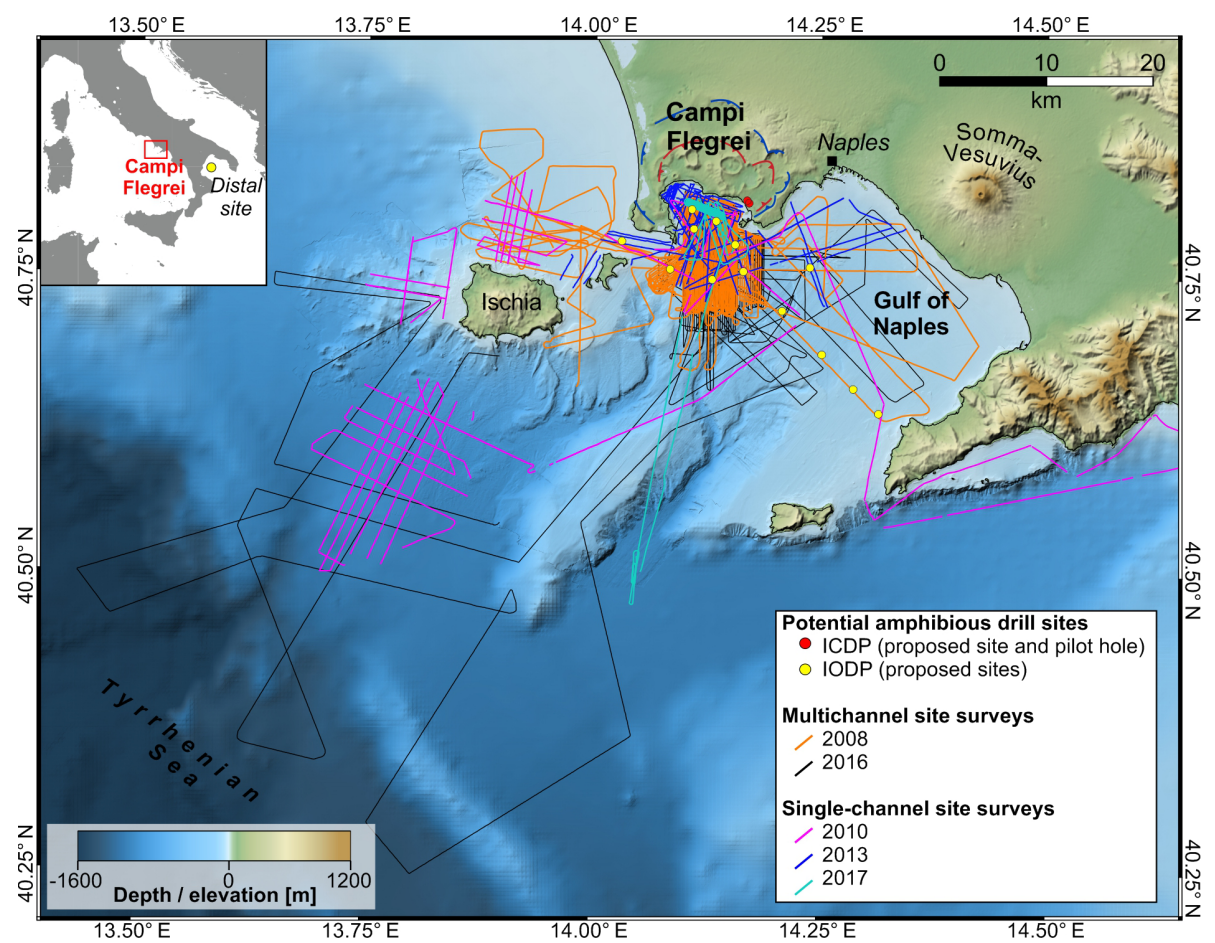

Figure 3. Offshore site-survey seismic data package (high-resolution multichannel and single-channel reflection seismic profiles) supporting the IODP component of the Campi Flegrei Amphibious Drilling Proposal. Locations of the proposed IODP drill sites and the ICDP site and pilot hole drilled in 2012 are also indicated.

e.g., volcano-earthquake interaction? In what way did the magmatic system change over time? Are there any major pre-CI ignimbrites originating from the Campanian Plain? What is the type of post-collapse, submarine volcanic activity? How have large eruptions changed the submarine morphology, and which are the syn- and post-eruptive deposition mechanisms?

- Difference between terrestrial and shallow marine volcanism. Why have post-collapse eruptions occurred preferentially in the onshore part of the caldera? Is the hydrothermal activity in the marine setting driving overpressure and fluid-saturated subvolcanic intrusions that are substantially different from on-land subvolcanic or volcanic processes?

- Environmental and climatic impact. This investigation refers to large-scale ignimbrite eruptions such as the CI and NYT events. Did these eruptions influence climate events? Did the CI eruption influence the decline of the Neanderthals? Do we recognize significant changes in the abundance and diversity of faunal and floral species after exceptionally large eruptions?

- Establishment of an in situ monitoring systems. This investigation regards the providing of optimal conditions for the quasi-real-time evaluation of critical parameters to be used as proxies to define the caldera dynamics.

\section{Rationale of the Campi Flegrei drilling proposal}

The outcomes of the workshop provided a conceptual framework for a full proposal for the drilling of the $\mathrm{CFc}$ to be submitted to the IODP and ICDP (Fig. 4) as an Amphibious Drilling Proposal. The Campi Flegrei ADP will combine complementary research topics into a general view on collapse-resurgent calderas located along continental margins. The partly submerged setting of the $\mathrm{CFc}$ provides a unique marine stratigraphic archive for a detailed reconstruction of the timing and kinematics of individual structures and components of the volcanic system, under different forcing factors (internal vs. external) during the past $10^{6}$ years (Fig. 5).

The drilling is important to reconstruct the subsurface 3D stratigraphic architecture, identify faults and volcanic or volcano-tectonic features, and obtain information on the hydrothermal discharge areas and thermal structure. It also provides valuable information concerning the eruptive history of volcanoes and the dynamics of eruptions with different intensity. Previous research in active volcanic areas has shown that drilling can be fundamental in clarifying and constraining structural interpretations based on geophysical data alone. For instance, drilling at the Kakkonda geothermal field in Japan revealed the steep permeability and lithological gradients where magmatic and hydrothermal regimes interact (Saito et al., 1997; Nakada, 2013). The IDDP-1 (Iceland 


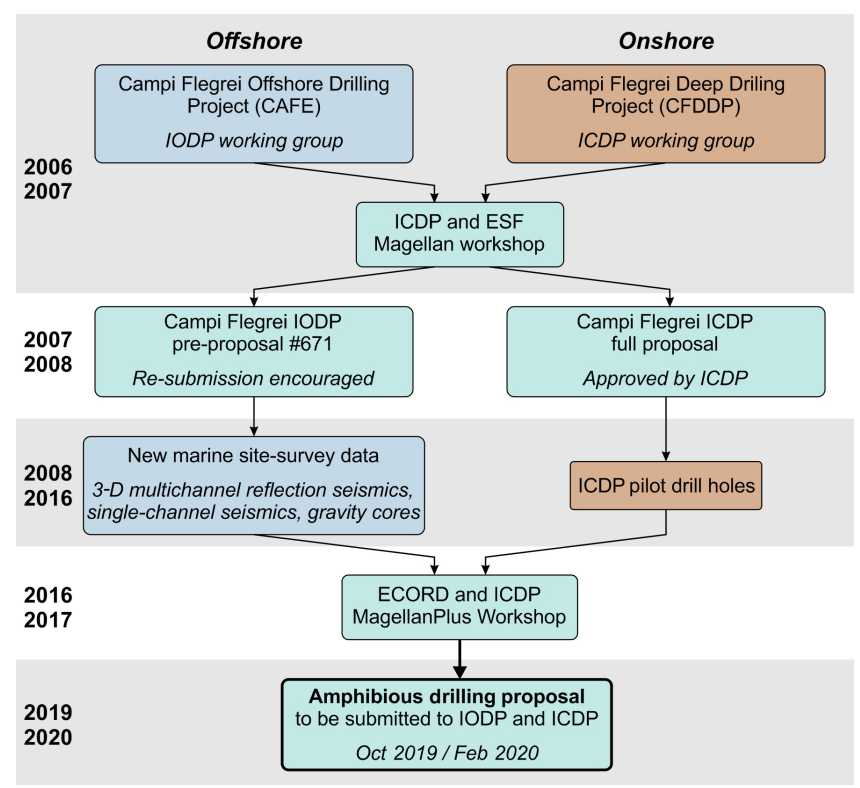

Figure 4. Flow chart illustrating the history of site-surveying activity and nurturing of the continental (ICDP) and marine (IODP) components of the Campi Flegrei Amphibious Drilling Proposal.

\begin{tabular}{|c|c|c|}
\hline \multirow{2}{*}{ Timescales } & \multicolumn{2}{|c|}{ Forcing } \\
\hline & Internal & External \\
\hline $\begin{array}{l}\text { Active - historical } \\
-\quad \text { Unrest, restlessness } \\
-\quad \text { Eruptions }\end{array}$ & $\begin{array}{l}\text { Fluids } \\
\text { Hydrothermalism } \\
\text { Magmatism (shallow / deep) }\end{array}$ & $\begin{array}{l}\text { Sea-level change } \\
\text { Tectonics }\end{array}$ \\
\hline $\begin{array}{l}10^{3}-10^{4} \text { yrs } \\
-\quad \text { Post-caldera recovery, resurgence } \\
-\quad \text { Uplift, eruptions }\end{array}$ & Magmatism (shallow) & $\begin{array}{l}\text { Sea-level change } \\
\text { Tectonics } \\
\text { Crustal } \\
\text { detumescence }\end{array}$ \\
\hline $\begin{array}{l}10^{5}-10^{6} \text { yrs } \\
-\quad \text { Volcanic-magmatic history } \\
-\quad \text { Cyclicity, periodicity }\end{array}$ & $\begin{array}{l}\text { Magmatism (flare-up) } \\
\text { Crust / mantle }\end{array}$ & $\begin{array}{l}\text { (Sea-level change?) } \\
\text { Tectonics }\end{array}$ \\
\hline
\end{tabular}

Figure 5. Timescales and forcing involved in the Campi Flegrei Amphibious Drilling Proposal (ADP).

Deep Drilling Project) well at Krafla in Iceland intercepted rhyolite melt in the region where geophysics had implied it would be absent (Elders et al., 2011). In the Long Valley Exploratory Well, a maximum temperature of $\sim 100^{\circ} \mathrm{C}$ was measured where the presence of shallow magma or at least very hot rock was assumed prior to drilling. Moreover, the use of selected drill holes as observatories provides an additional advantage for the in situ monitoring of volcanic and/or hydrothermal activity.

Drilling into active volcanic areas is not completely without risk, even though previous experiments in Japan and Iceland (Saito et al., 1997; Nakada, 2013; Elders et al., 2011) suggest that the chance of triggering a volcanic eruption is extremely small. The main risks are the hazards of possible underground pressure blowouts, meeting zones of fluid loss and material failure, and, more rarely, surface emission of liquefied sediments and steam (e.g., Sawolo et al., 2009). Documented experience indicates, however, that these risks can be significantly reduced or prevented by applying the appropriate mitigation techniques (e.g., blowout preventer systems) (e.g., Homuth et al., 2010).

\subsection{Drilling at Campi Flegrei}

The workshop was successful in identifying a number of relevant topics and questions, whose response may solve fundamental problems related to the caldera volcanism.

a. The Campi Flegrei caldera represents an ideal example of an active caldera located in a shallow-water setting $(<200 \mathrm{~m}$ water depth). Other ODP Legs (Ocean Drilling Program) (e.g., ODP Leg 157: Gran Canaria and Madeira Abyssal Plain) and IODP Expeditions (e.g., IODP Expedition 340: Lesser Antilles Volcanism and Landslides) have focused on volcanic islands in deep oceanic settings. Campi Flegrei provides a unique opportunity to obtain a high-resolution stratigraphic archive of explosive, effusive, and extrusive volcanism, volcano-tectonic dynamics, and unrest. Moreover, the proximal marine setting of the $\mathrm{CFc}$ documents the primary deposition and reworking of pyroclastic currents and fall deposits as components of the continental shelf slope system.

b. Campi Flegrei is a primary site to unravel the timing, structure, and evolution of caldera resurgence and unrest based on the geological record of marine strata. The mixed marine siliciclastic-volcaniclastic depositional architecture of the caldera fill provides a unique opportunity to document the pattern, timing, and rates of deformation related to resurgence since the Late Pleistocene. The last two millennia of documented unrest also provide further constraints in reconstructing time series of deformation onshore and offshore.

c. The Campi Flegrei caldera generated the largest explosive eruptions in Europe during the Late Quaternary. The results of drilling and well logging will have a high potential impact on paleoenvironmental-paleoclimatic reconstruction. The coupling of proximal drill sites off Pozzuoli Bay with the results from the drilling of the distal stratigraphic record will also help in reconstructing the dispersal and erosive patterns of co-ignimbritic tephras. Also, this record could provide some insights into the puzzling issue of the apparent causal relationships between the environmental effects of the CI eruption and the final decline of Neanderthals.

d. Drilling off the shore of the Campi Flegrei caldera will help investigate the interaction between the magmatic and hydrothermal systems and the occurrence of a wide range of subaerial-to-submarine features from 
monogenic volcanoes to hydrothermal vents. The apparent difference between the onshore and offshore evolution may be related to changing magma-water interactions under saturated conditions within the mixing zone between the phreatic and marine pore waters, and this can only be investigated in detail by an onshoreoffshore drilling transect. Long-term borehole monitoring of physical, chemical, and microbiological parameters may additionally provide a chance to identify the potential precursors to eruptions for the purpose of risk mitigation.

\subsection{Amphibious drilling}

The half-submerged setting of the $\mathrm{CFc}$ provides an opportunity to integrate results from offshore and onshore drillings and available marine geology and volcanological data. A deep, onshore borehole $(\sim 3 \mathrm{~km})$ will allow the processes responsible for the recent unrest to be investigated at depth through the determination of rock physical properties, magma-water interaction, and water fluid chemical and physical exchanges. For instance, (1) extrapolated temperature measurements can be used to detect the depth of magmatic intrusions and the hydrothermal system; (2) the in situ chemical composition of fluids will provide information on rapid changes in the magmatic-hydrothermal system; and (3) deep monitoring systems will be deployed and incorporated in the existing network of the INGV-Napoli (Istituto Nazionale di Geofisica e Vulcanologia) (Osservatorio Vesuviano) to enable real-time tracking of such changes.

At the same time, a robust site-survey database, consisting of several multi-frequency (even 3-D) reflection seismic datasets (both single-channel and multichannel) has been acquired since 2008, yielding high-resolution images of the uppermost $100 \mathrm{~m}$ of the crust as well as new images to a depth of $1-2 \mathrm{~km}$. Such a comprehensive database will enable a precise selection of offshore drill sites and guidance regarding deviated onshore drilling. The recent discovery of previously unknown volcanic structures and hydrothermal vents offshore offers a high potential for an integrated stratigraphic reconstruction (e.g., Sacchi et al., 2009, 2014; Passaro et al., 2016; Steinmann et al., 2016, 2018). The combined observations and data call for a joint offshore and onshore drilling program in order to (a) obtain an improved chronostratigraphic correlation between intra-caldera and extra-caldera products and (b) understand the origin of caldera collapse and the mechanisms of resurgence. An ideal drilling strategy at Campi Flegrei would therefore include the following onshore and offshore coordinated components:

a. Onshore drilling and well logging down to a depth in the order of $3000 \mathrm{~m}$ to investigate the caldera deep structure and associated deep magmatic-hydrothermal system. The drilling will provide the opportunity to investigate the processes responsible for the recent unrest episodes at depth, thereby allowing for a reliable evaluation of the hazard. This component includes (1) the acquisition of physical-chemical parameters of the geothermal system over the entire depth; (2) stress measurements (size and direction) at depth; (3) the permeability measurements at depth; (4) the extrapolation of temperatures in the supercritical layer to detect the depth of the magmatic temperature and locate magmatic intrusions; and (5) the determination of the physical, mechanical, and rheological parameters of deep rocks.

b. Offshore drilling down to a maximum depth of $\sim 1000 \mathrm{~m}$ to investigate the shallow structural levels of the caldera fill and resurgence as well as to unravel the mechanisms of magma-water interaction as a function of depth. This component provides the opportunity to study an undisturbed sedimentary archive without the challenges posed on land by intense subaerial erosion or urbanization (i.e., inaccessibility). This implies a much higher potential for structural, geochronological, petrographic, and geochemical reconstruction. Hence, marine drilling will provide a complete high-resolution stratigraphic record which will (1) improve the chronostratigraphy of volcanic and sedimentation events and unlock the timing and structural style of the deformation associated with inner-caldera resurgence, (2) understand the climatic effects and the environmental impact of ignimbrite eruptions on life and ecosystems, and (3) investigate the impact of magmatic-hydrothermal processes with respect to hydrothermal vents and shallow degassing structures as well as submarine monogenetic volcanoes and intrusions.

\section{Drilling objectives and borehole logging and monitoring strategies}

The workshop participants suggested that the IODP component of the ADP proposal should address the integrated stratigraphy of the caldera fill and resurgence, petrology, fluid geochemistry, and architecture of shallow structural levels $(<1000 \mathrm{~m}$ depth), whereas the ICDP component should focus on rock-fluid properties, physical-chemical processes, and the geothermal system at greater depth $(<3000 \mathrm{~m})$. The proposed drilling strategy includes one major onshore drilling, complemented by an amphibious drilling transect extending from the Campi Flegrei shoreline towards the SE border of Naples Bay, together with distal drill sites in the Adriatic and Ionian Seas (Figs. 2, 6-12 and Table 1). Down-hole logging and long-term borehole monitoring at selected drill sites of primary physical and chemical parameters, along with microbiological analysis of rocks and fluids, within a depth range with a maximum of $0.5-1.0 \mathrm{~km}$, have been also included in the planned operations. 


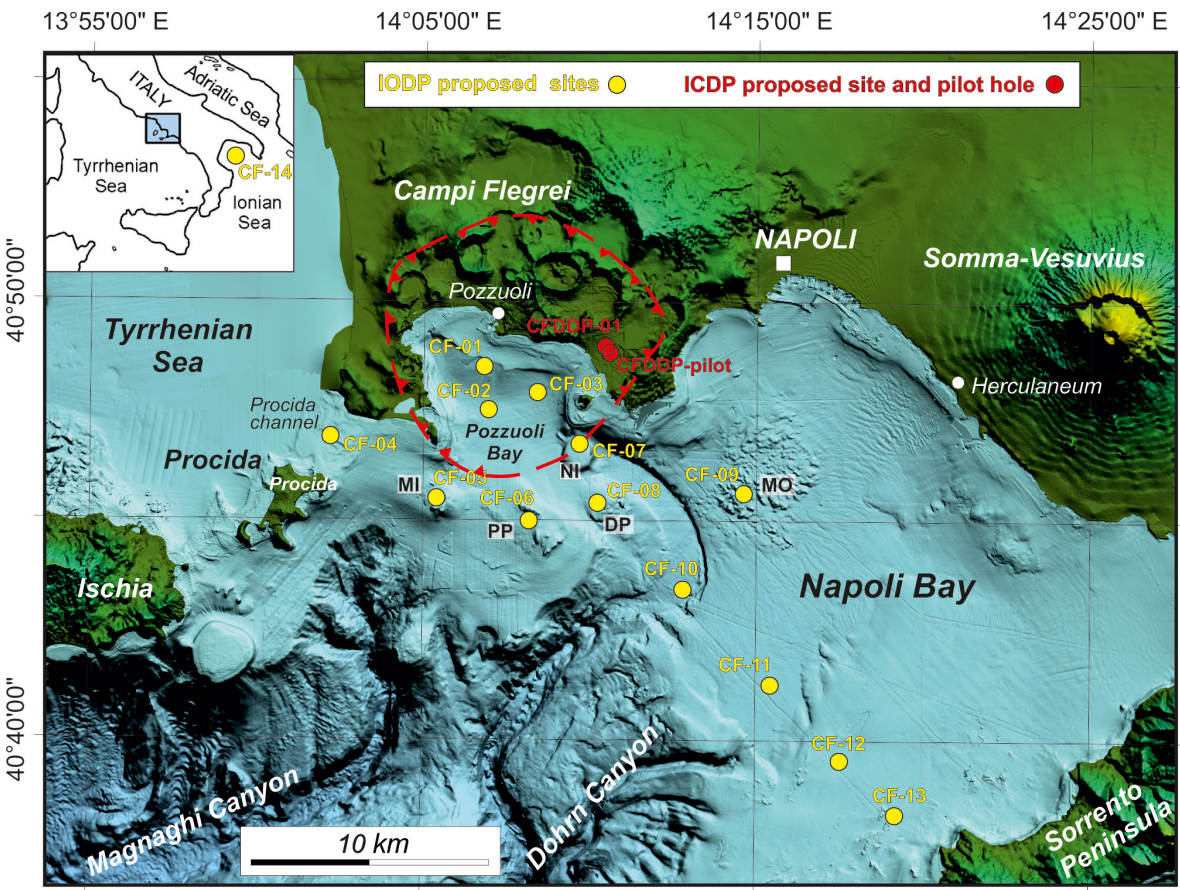

Figure 6. Location of onshore and offshore drill sites included in the first-draft plan of the Campi Flegrei Caldera Amphibious Drilling Proposal discussed during the MagellanPlus workshop.

\section{Campi Flegrei collapse-resurgent caldera}

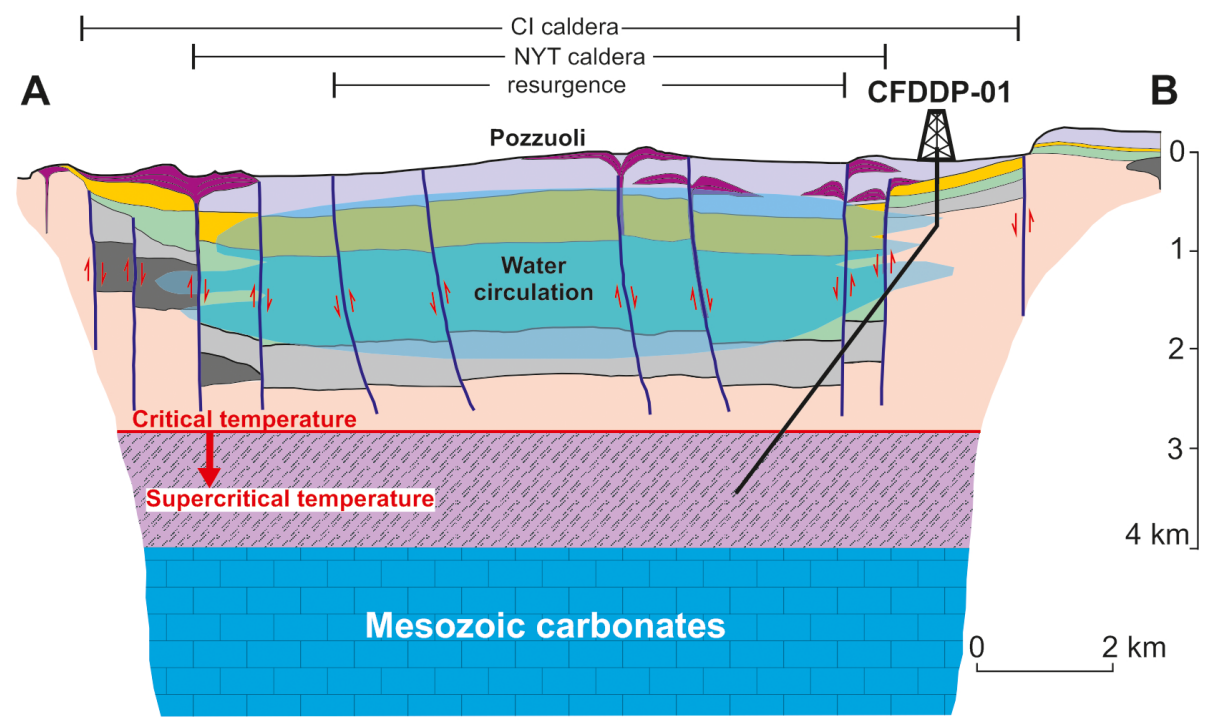

Volcaniclastic and marine siliciclastic deposits $(<15 \mathrm{ka})$

Neapolitan Yellow Tuff (NYT) (15 ka)

Volcaniclastic and marine siliciclastic deposits (39-15 ka)

Campania Ignimbrite $(\mathrm{Cl})(39 \mathrm{ka})$

Volcanic rocks (>39 ka); a: pyroclastics; b: lavas

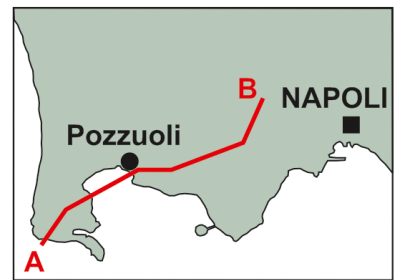

Figure 7. Illustrated section of the Campi Flegrei caldera structure indicating the targets of the proposed onshore (ICDP) drill site (CFDDP01). The reconstruction is mostly based on geophysical and geological data, affected by large uncertainties. The depth limit critical water temperature is constrained by previous drillings in the area (AGIP, 1987). Modified after De Natale and Troise (2011). 
Table 1. Summary of proposed onshore and offshore drill sites for the Campi Flegrei Caldera Amphibious Drilling Proposal (ADP).

\begin{tabular}{|c|c|c|c|c|c|}
\hline $\begin{array}{l}\text { ADP } \\
\text { component }\end{array}$ & $\begin{array}{l}\text { Proposed drill } \\
\text { site }\end{array}$ & $\begin{array}{l}\text { Structural } \\
\text { sector }\end{array}$ & Drilling targets & $\begin{array}{l}\text { Drilling } \\
\text { depth }(\mathrm{m})\end{array}$ & Remarks \\
\hline ICDP & CFDDP-01 & Caldera margin & $\begin{array}{l}\text { Stratigraphically reconstruct and } \\
\text { well log through the hydrother- } \\
\text { mal system down to the brittle and } \\
\text { ductile zone }\end{array}$ & $\sim 3000$ & $\begin{array}{l}\text { Deviated well, directed from the } \\
\text { eastern border of the caldera to- } \\
\text { wards the caldera center at depth }\end{array}$ \\
\hline IODP & CF-01 & Caldera center & $\begin{array}{l}\text { Sample the stratigraphic succes- } \\
\text { sion of NYT caldera fill and pene- } \\
\text { trate the structural caldera floor }\end{array}$ & $\sim 900$ & $\begin{array}{l}\text { Deep offshore well within the } \\
\text { caldera collapse area; maximum } \\
\text { drilling depth to be agreed on with } \\
\text { safety panels }\end{array}$ \\
\hline IODP & $\mathrm{CF}-02$ & $\begin{array}{l}\text { Flanks of the } \\
\text { resurgent dome }\end{array}$ & $\begin{array}{l}\text { Drill the post- } 15 \text { ka caldera fill to } \\
\text { reconstruct the timing of deforma- } \\
\text { tion and uplift of the caldera resur- } \\
\text { gence }\end{array}$ & $\sim 50$ & $\begin{array}{l}\text { Unique place to study the timing of } \\
\text { the deformation of a caldera resur- } \\
\text { gent structure }\end{array}$ \\
\hline IODP & CF-03 & Caldera collar & $\begin{array}{l}\text { Drill the subsurface magmatic in- } \\
\text { trusion and hydrothermal vent off } \\
\text { the shore of Bagnoli }(12-8 \mathrm{ka})\end{array}$ & $\sim 120$ & $\begin{array}{l}\text { Subsurficial intrusion }(6-4 \mathrm{ka}) \text {; } \\
\text { magma-water interaction; implica- } \\
\text { tions for volcanic hazard }\end{array}$ \\
\hline IODP & $\mathrm{CF}-04$ & $\begin{array}{l}\text { Caldera periph- } \\
\text { ery }\end{array}$ & $\begin{array}{l}\text { Drill the CI deposits in the shal- } \\
\text { low subseafloor of Procida Chan- } \\
\text { nel }\end{array}$ & $\sim 100$ & Proximal facies of the CI \\
\hline IODP & CF-05 & $\begin{array}{l}\text { Caldera periph- } \\
\text { ery }\end{array}$ & $\begin{array}{l}\text { Drill the stratigraphic succes- } \\
\text { sion of the peri-caldera mono- } \\
\text { genic volcano of Miseno Bank } \\
(>120 \mathrm{ka})\end{array}$ & $\sim 80$ & Pre-caldera volcanism \\
\hline IODP & CF-06 & $\begin{array}{l}\text { Caldera periph- } \\
\text { ery }\end{array}$ & $\begin{array}{l}\text { Drill the stratigraphic succession } \\
\text { of the peri-caldera volcanic ap- } \\
\text { paratus of Penta Palummo Bank } \\
(>120 \mathrm{ka})\end{array}$ & $\sim 80$ & Pre-caldera volcanism \\
\hline IODP & CF-07 & $\begin{array}{l}\text { Caldera struc- } \\
\text { tural border }\end{array}$ & $\begin{array}{l}\text { Drill the stratigraphic succession } \\
\text { of Nisida Bank (ca. 18-15 ka) }\end{array}$ & $\sim 100$ & Caldera-related volcanism \\
\hline IODP & CF-08 & $\begin{array}{l}\text { Caldera periph- } \\
\text { ery }\end{array}$ & $\begin{array}{l}\text { Drill the subsurficial intrusion and } \\
\text { hydrothermal vent of Mt. Dolce- } \\
\text { Pampano Bank (8-4 ka) }\end{array}$ & $\sim 250$ & $\begin{array}{l}\text { Subsurficial intrusion ( } 18-15 \mathrm{ka}) \text {; } \\
\text { magma-water interaction; implica- } \\
\text { tions for volcanic hazard }\end{array}$ \\
\hline IODP & CF-09 & $\begin{array}{l}\text { Caldera exter- } \\
\text { nal periphery }\end{array}$ & $\begin{array}{l}\text { Drill the volcaniclastic diapirs } \\
\text { and mounds associated with hy- } \\
\text { drothermal venting at Montagna } \\
\text { Bank }(15-5 \mathrm{ka})\end{array}$ & $\sim 150$ & $\begin{array}{l}\text { Soft-sediment deformation and vol- } \\
\text { caniclastic diapirism triggered by } \\
\text { overpressured fluids }\end{array}$ \\
\hline IODP & $\begin{array}{l}\text { CF-010 } \\
\text { CF-011 } \\
\text { CF-012 } \\
\text { CF-013 }\end{array}$ & $\begin{array}{l}\text { Proximal } \\
\text { caldera exterior }\end{array}$ & $\begin{array}{l}\text { Drill the Upper Quaternary } \\
\text { mixed siliciclastic-volcaniclastic } \\
\text { succession of Naples Bay for a } \\
\text { stratigraphic purpose }\end{array}$ & $\begin{array}{l}\sim 200 \\
\sim 200 \\
\sim 200 \\
\sim 200\end{array}$ & $\begin{array}{l}\text { Drilling transect for the recovery } \\
\text { of a composite stratigraphic sec- } \\
\text { tion; proximal stratigraphic record } \\
\text { of Campi Flegrei eruptions }\end{array}$ \\
\hline IODP & $\mathrm{CF}-014$ & $\begin{array}{l}\text { Distal caldera } \\
\text { exterior }\end{array}$ & $\begin{array}{l}\text { Sample distal products of major } \\
\text { explosive events from Campi Fle- } \\
\text { grei and other eruptive centers of } \\
\text { the Campanian district }\end{array}$ & $\sim 100$ & Distal tephrostratigraphy \\
\hline
\end{tabular}




\section{CFDDP Pilot borehole}

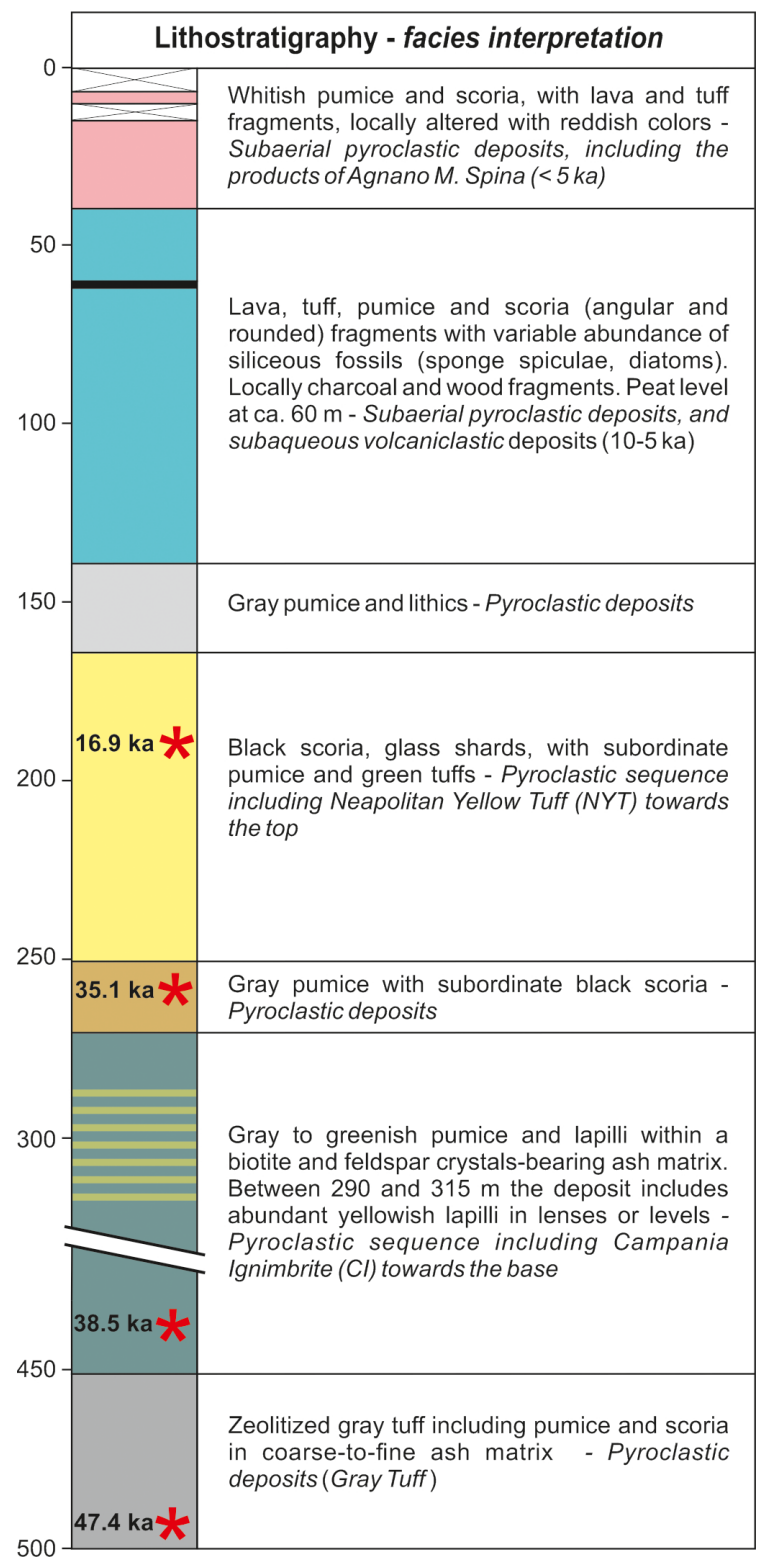

Figure 8. Synthetic lithostratigraphy and facies interpretation of the succession sampled at the CFDDP pilot borehole $(500 \mathrm{~m})$ on the shore of Bagnoli in 2012 (modified after De Natale et al., 2016). Red asterisks indicate the depth and ${ }^{40} \mathrm{Ar} /{ }^{39} \mathrm{Ar}$ age of sampled $\mathrm{K}$ feldspars. See Figs. 2-3 and 6 for the location of the borehole site.

\subsection{Proposed on-land drill site (ICDP component)}

\section{Caldera margin to center}

By drilling a $\sim 3 \mathrm{~km}$ long deviated well from the eastern caldera margin towards its center (site CFDDP-01), we will be able to obtain a reference stratigraphic succession of the $\mathrm{CFc}$ fill to the basement floor and conduct well logging through the hydrothermal system down to the brittle and ductile zone (Figs. 2, 6-7 and Table 1).

Another important component of the on-land drilling will be the deployment of a network of in situ monitoring stations at depth to provide real-time insights into changes in the hydrothermal-volcanic system. Such information is crucial to understanding the ongoing unrest as well as to reliably assessing hazards and risks. The drilling of site CFDDP-01 will rely on the results of the $500 \mathrm{~m}$ deep pilot hole and associated well log data acquired by the INGV-Napoli in 2012 (Figs. 2, 6 and 8).

\subsection{Proposed offshore drill sites (IODP component)}

\subsubsection{Caldera center - caldera fill, resurgent dome, and structural floor}

The caldera fill represents a high-resolution archive of the post-caldera volcanic succession, as well as a record of the ground deformation caused by caldera resurgence. Hence, drilling the caldera fill will facilitate (1) the discovery of new insights regarding post-caldera volcanic history, (2) the reconstruction of the timing, duration, and conditions of caldera resurgence, and (3) understanding the caldera's subsurface structure. Penetrating the floor of the caldera (site CF-01) will provide conclusive information on the precaldera phase and caldera formation processes. Site CF-02 is designed to recover the stratigraphic succession that formed over the flanks of the resurgent structure, in order to provide ages and timing of volcano-tectonic deformation since the NYT caldera collapse (last 15000 years) (Figs. 2, 6, 9-11 and Table 1).

\subsubsection{Caldera collar - fractured, permeable zone}

The annular depression ("collar") between the structural border of the NYT caldera and the inner-caldera resurgent dome is a highly fractured zone, characterized by ascending fluids and locally shallow magmatic intrusions. The area represents a remarkably permeable segment of the caldera structure and is a key location to study the interconnection between the deep magmatic-hydrothermal system and the surface and its role during caldera unrest. Site CF- 03 is planned to drill through the shallow structural levels of the ring-fault zone of the NYT caldera collar down to small laccolith-like intrusion off the shore of Bagnoli (Figs. 2, 6, 9-10 and Table 1). Drilling operations will be limited to shallow depths $(<150 \mathrm{~m})$ and will be only realized after stepwise monitoring of temperature and fluid pressure.

\subsubsection{Caldera structural border - pre-NYT caldera vents and intrusions}

The outer border of the $\mathrm{CFc}$ is characterized by a number of offshore vents, shallow magmatic intrusions, and ignimbrite 
NYT Caldera - Campi Flegrei

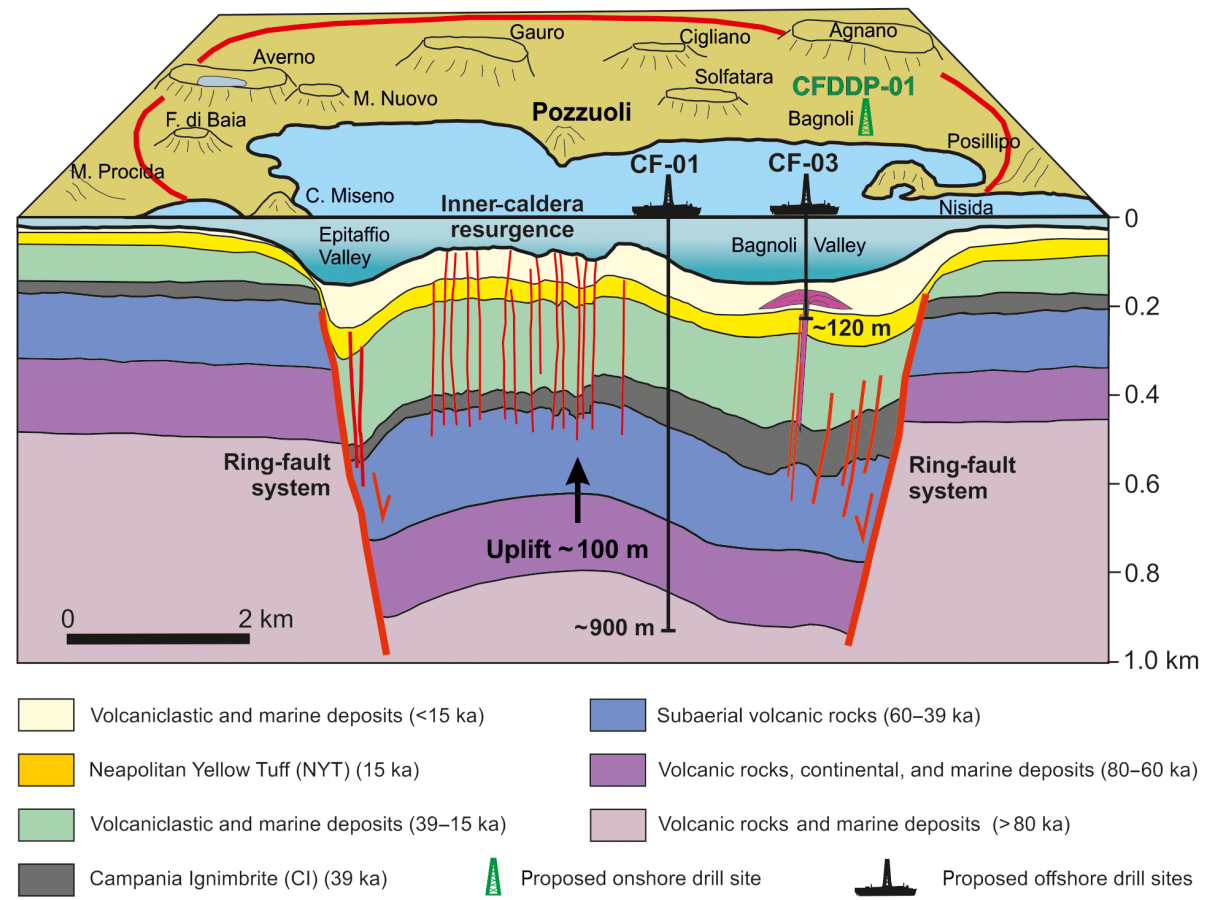

Figure 9. Schematic reconstruction of the shallow structure $(<1 \mathrm{~km})$ of the collapse-resurgent caldera associated with the eruption of the Neapolitan Yellow Tuff (NYT) and the location of the proposed offshore (IODP) drill sites CF-01 and CF-03.

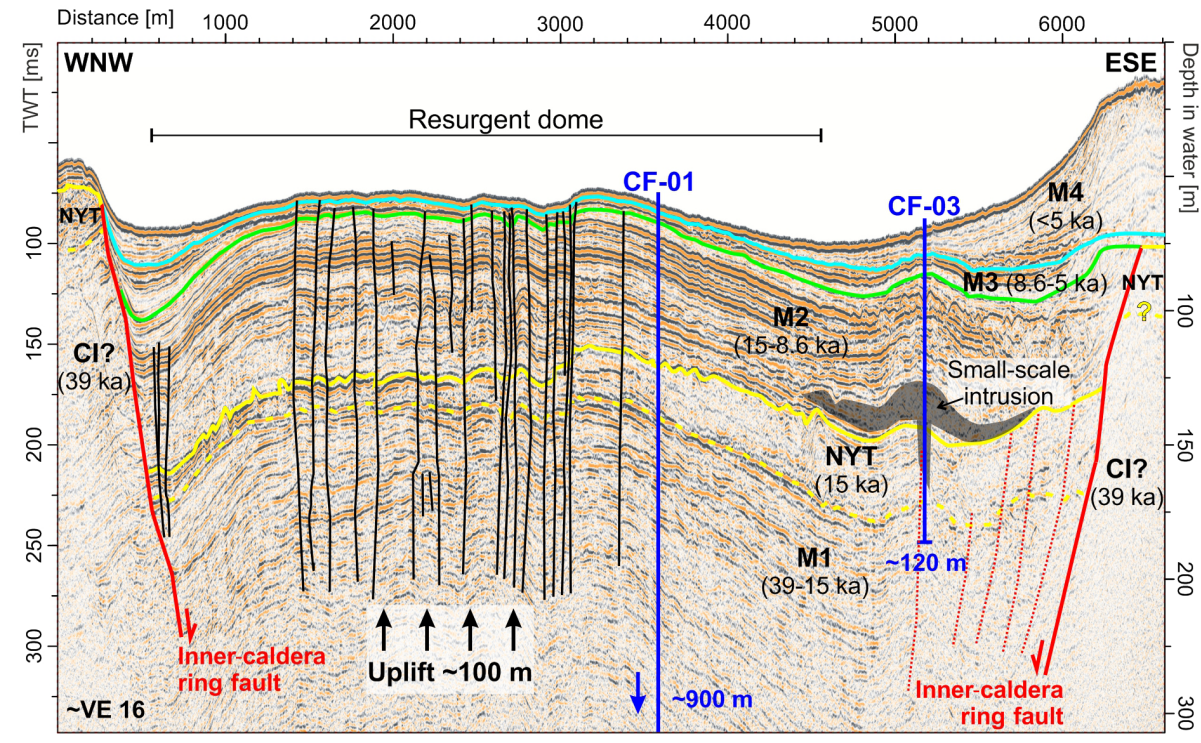

Figure 10. Interpreted high-resolution multichannel seismic profile across the CF caldera center and proposed location of drill sites $\mathrm{CF}-01$ and CF-03. M1-M4 are the inner-caldera marine siliciclastic units; CI is Campanian Ignimbrite; NYT is Neapolitan Yellow Tuff.

deposits ranging in age from $\sim 120$ to $\sim 18 \mathrm{ka}$. These provide a spectrum of volcanic features produced by significant magma-water interaction. They include most of the volcanic banks of the southern periphery of Pozzuoli Bay and $\mathrm{CI}$ ignimbrite deposits occurring at shallow depths beneath the seafloor, mostly between Procida and the mainland. Drill sites will aim to characterize the nature of these volcanic centers and units and their role in the onset of pre-CFc volcanism and the overall fluid circulation (as, for instance, Nisida Bank represents an active fluid vent). Drilling at site CF-04 


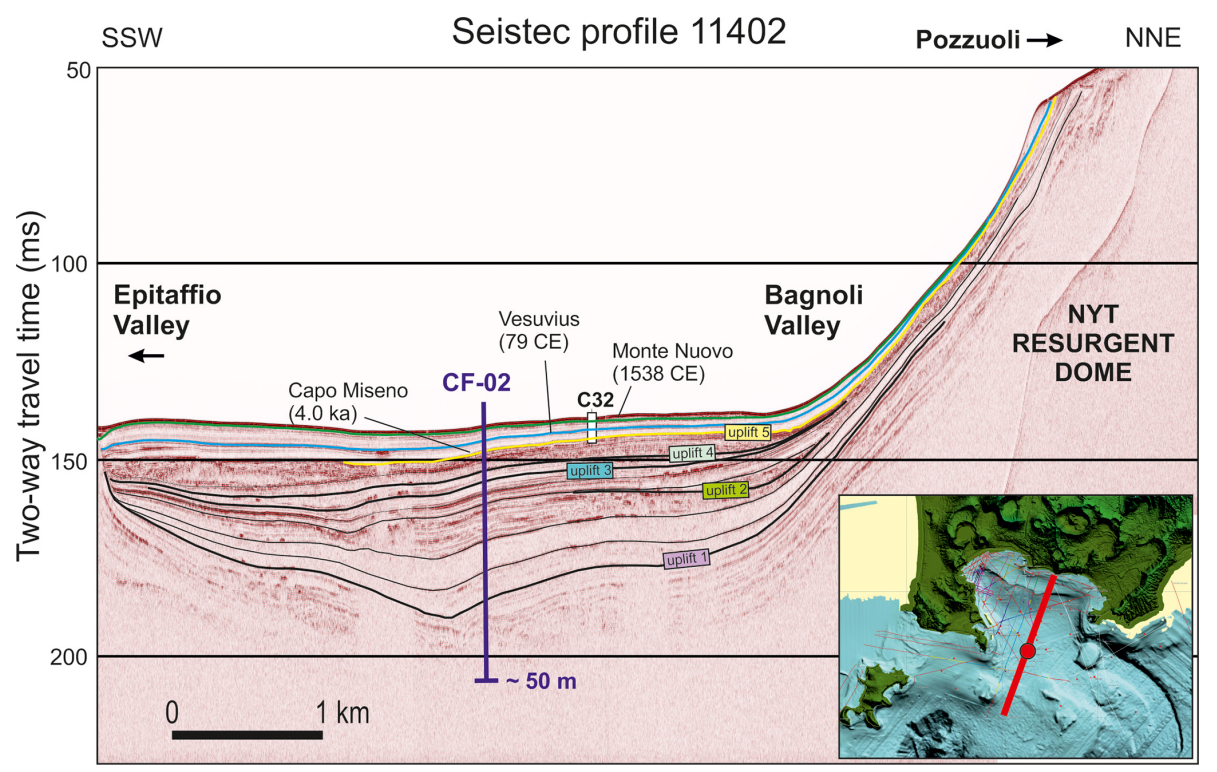

Figure 11. High-resolution single-channel seismic profile across the southern slope of the NYT resurgent dome and proposed location of drill site CF-02. Unconformities labeled as uplift 1-5 are interpreted as the result of a series of seafloor deformation phases associated with phases of the deformation of the resurgent structure. Correlation of tephra layers sampled by gravity core C32 is after Sacchi et al. (2014).

(Procida Channel) will focus on the recovery of a proximal succession of the CI. Drill sites CF-05 and CF-08 have been proposed to recover stratigraphic successions from a series of volcanic banks, namely at sites CF-04 (Miseno Bank), CF05 (Penta Palummo Bank), CF-06, (Nisida Bank), and CF-07 (Mt. Dolce-Pampano Bank) (Figs. 2, 6 and Table 1).

\subsubsection{Proximal extra-caldera area - Bay of Naples}

Significant fluid venting in the Bay of Naples is not restricted to the ring-fault zone of the $\mathrm{CFc}$, but it also occurs outside the structural border of the caldera itself. This is the case of Montagna Bank, a sub-circular seafloor region SE of Pozzuoli Bay that was formed by the dragging and rising up of volcaniclastic diapirs (consisting mostly of unconsolidated pumice), due to pore fluid overpressure at depth and associated fluid migration towards the seafloor (Passaro et al., 2016). Site CF-08 has been designed to drill through the volcaniclastic diapirs of Montagna Bank to the roots of the unconsolidated sediments involved in this process. The Naples Bay half-graben also represents an expanded, undisturbed sedimentary succession with interbedded massive ignimbrite deposits (NYT and CI). An offset drilling (CF-10 to CF-13) is an opportunity to cover a large time span of 1 million years (exceeding the entire time span of volcanic activity) with a transect of relatively shallow $(\sim 200 \mathrm{~m})$ drillings (Figs. 2, 6 and Table 1). This will provide novel insights into the overall eruption history of the entire Campi Flegrei area and its tectonic evolution. Also, by drilling large ignimbrite units from top to bottom (i.e., contact zone of ignimbrite and siliciclastic units), their environmental impact and subsequent the recovery of life after major eruptions can be investigated.

\subsubsection{Distal extra-caldera area - Ionian Sea}

A distal drill site (CF-14) has been proposed to recover an undisturbed pyroclastic fallout archive allowing for an integrated tephrostratigraphic analysis of the entire eruptive history of the Campi Flegrei area and other eruptive centers in the Campanian region (Figs. 6 and 12).

\subsection{Down-hole logging and borehole monitoring strategies}

The well logging plan incorporates a wide spectrum of downhole measurements which are designed to acquire maximum in situ information on petrophysical and geomechanical properties, as well as enhance monitoring of the strain-stress conditions, active seismicity, and the hydrothermal system at depth. The main parameters to be measured include (1) natural gamma rays, radioactivity, and spectrometry; (2) resistivity; (3) spontaneous potential redox; (4) sonic log; (5) magnetic susceptibility; (6) hole diameter (caliper); (7) temperature; (8) oriented microresistivity; and (9) acoustic and ultrasonic borehole images. The use of long-term borehole observatories (e.g., down-hole broadband seismic stations equipped with newly developed opto-electronic strain sensors and advanced monitoring systems that incorporate multiple seals allowing zoned measurements of in situ physical, chemical, and biological properties) may be considered for sites CFDDP-01 and CF-01. 


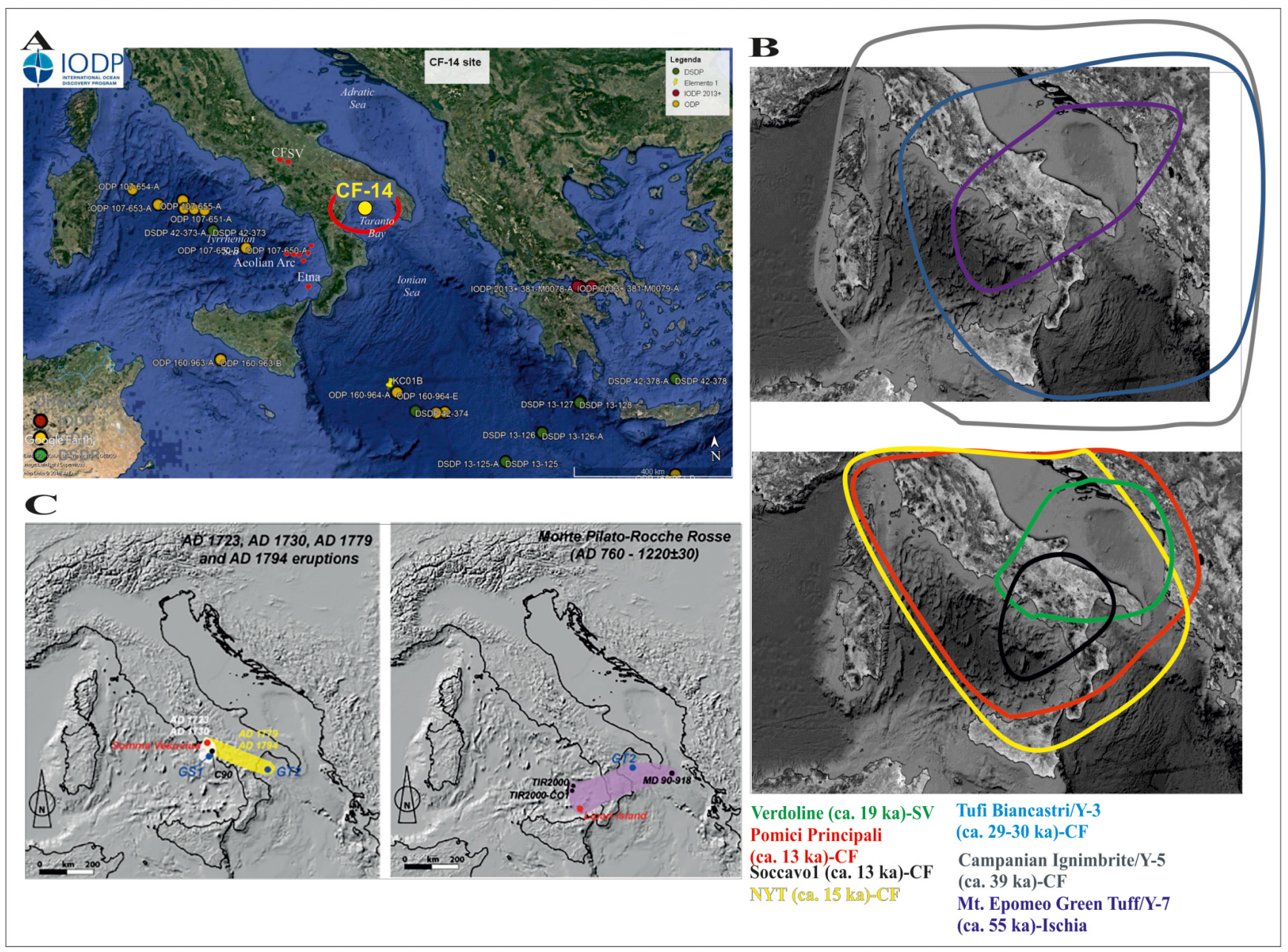

Figure 12. Proposed site CF-14 (Ionian Sea) for distal tephrostratigraphic reconstruction of Late Quaternary volcanism of the Campanian region (Crocitti et al., 2018; Di Donato et al., 2019). (a) Location map with an indication of the main DSDP (Deep Sea Drilling Project), ODP, and IODP archives (yellow for marine and green for terrestrial) of the central Mediterranean region; (b) dispersal maps of plinian and sub-plinian events (Bronk-Ramsey et al., 2015); (c) dispersal maps of moderately explosive eruptions (Sulpizio et al., 2014; Crocitti et al., 2018). Please note that the years given in AD in Fig. 12c correspond to those same years in the CE notation system.

\section{Concluding remarks}

Every eruption is preceded by unrest, but not every unrest culminates in an eruption (Acocella et al., 2015; Newhall and Dzurisin, 1988). Understanding the driving forces of volcanic unrest and the role of magmatic-hydrothermal processes is thus crucial for reliable hazard assessment. During the MagellanPlus workshop, all participants agreed that the $\mathrm{CFc}$ represents an ideal natural laboratory to study the interaction among volcanic, hydrothermal, marine, and volcanotectonic processes. The amphibious Campi Flegrei drilling project, involving a deep ICDP and shallower IODP drillings, will address fundamental aspects including phreatic and hydromagmatic volcanism, caldera formation and subsequent structural resurgence and post-caldera volcanism, fallout and ignimbrite stratigraphy, hydrothermal-magma interactions, mechanisms of volcanic unrest, and volcano-tectonic cou- pling. The results will significantly advance our understanding of the most complex forms of volcanic structures on Earth.

Data availability. The onshore data supporting the work presented in this report are available at the INGV-Napoli (Giuseppe De Natale: giuseppe.denatale@ingv.it); offshore data are available at the Faculty of Geosciences of the University of Bremen (Volkhard Spiess: vspiess@uni-bremen.de) and CNR-ISMAR, Naples (Marco Sacchi: marco.sacchi@cnr.it).

Author contributions. MSa, GDN, VS, and LS jointly organized the workshop. MSa, GDN, LS, CK, and SDS drafted the paper. MSa, LS, and DI created the figures. All co-authors jointly contributed to the formulation of the concepts, scientific questions, and 
drilling/logging strategies discussed in the paper, according to their expertise: volcanology (SDS, NG, CS, HUS, MSu, and GV), petrology (LF), physical volcanology and volcanic hazards (GDN, VA, $\mathrm{CK}, \mathrm{AF}, \mathrm{SP}, \mathrm{RS}$, and CT), integrated stratigraphy (MSa, FM, and MV), structural geology of volcanic margins (VA, GV, and FP), tephrochronology (DI, PP, and ST), marine geophysics (VS, LS, SP, $\mathrm{FP}$, and $\mathrm{MC}$ ), and borehole logging (MJJ).

Competing interests. The authors declare that they have no conflict of interest.

Acknowledgements. This report summarizes the results of the MagellanPlus workshop "Structure and Evolution of Magmatic and Hydrothermal Systems in offshore collapse-resurgent calderas Development of an IODP Drilling Proposal at Campi Flegrei (Eastern Tyrrhenian Margin) linking to active ICDP Drilling Initiatives" (25-28 February, Naples, Italy). The authors wish to thank the two anonymous reviewers for their critical comments and suggestions on the early version of the manuscript.

Financial support. This research has been supported by the European Consortium for Ocean Research Drilling (ECORD) through the ECORD/ICDP MagellanPlus Workshop Series Programme (grant no. 2017.2376/4/AF).

Review statement. This paper was edited by Tomoaki Morishita and reviewed by two anonymous referees.

\section{References}

Acocella, V., Salvini, F., Funiciello, R., and Faccenna, C.: The role of transfer structures on volcanic activity at Campi Flegrei (Southern Italy), J. Volcanol. Geoth. Res., 91, 123-139, 1999.

Acocella, V., Cifelli, F., and Funiciello, R.: Analogue models of collapse calderas and resurgent domes. J. Volcanol. Geoth. Res., 104, 81-96, 2000.

Acocella, V., Cifelli, F., and Funiciello, R.: The control of overburden thickness on resurgent domes: insights from analogue models, J. Volcanol. Geoth. Res., 111, 137-153, 2001.

Acocella, V., Funiciello, R., Marotta, E., Orsi, G., and de Vita, S.: The role of extensional structures on experimental calderas and resurgence, J. Volcanol. Geoth. Res., 129, 199-217, 2004.

Acocella, V., Di Lorenzo, R., Newhall, C., and Scandone, R.: An overview of recent (1988 to 2014) caldera unrest: Knowledge and perspectives, Rev. Geophys., 53, 1-60, https://doi.org/10.1002/2015RG000492, 2015.

AGIP: Geologia e Geofisica del Sistema Geotermico dei Campi Flegrei, Technical Report, SERG-ESG, San Donato, Italy, 1-23, 1987.

Battaglia, M., Troise, C., Obrizzo, F., Pingue, F., and De Natale, G.: Evidence for fluid migration as the source of deformation at Campi Flegrei caldera (Italy), Geophys. Res. Lett., 33, 1-4, 2006.

Bellucci, F., Milia, A., Rolandi, G., and Torrente, M. M.: Structural control on the Upper Pleistocene ignimbrite eruptions in the Neapolitan area (Italy): volcano tectonic faults versus caldera faults, in: Volcanism in the Campania Plain: Vesuvius, Campi Flegrei and Ignimbrites, edited by: De Vivo, B., Elsevier B. V., Amsterdam, the Netherlands, 163-180, 2006.

Berrino, G., Corrado, G., Luongo, G., and Toro, B.: Ground deformation and gravity changes accompanying the 1982 Pozzuoli uplift, B. Volcanol., 47, 188-200, 1984.

Bronk-Ramsey, C., Albert, P. G., Blockley, S. P. E., Hardiman, M., Housley, R. A., Lane, C. S., Lee, S., Matthews, I. P., Smith, V. C., and Lowe, J. J.: Improved age estimates for key Late Quaternary European tephra horizons in the RESET lattice, Quaternary Sci Rev., 118, 18-32, 2015.

Burov, E. B. and Guillou-Frottier, L.: Thermomechanical behavior of large ash flow calderas, J. Geophys. Res., 104, 23081-23109, 1999.

Chiodini, G., Vandemeulebrouck, J., Caliro, S., D’Auria L., De Martino P., Mangiacapra A., and Petrillo, Z.: Evidence of thermal-driven processes triggering the 2005-2014 unrest at Campi Flegrei caldera, Earth Planet. Sc. Lett., 414, 58-67, 2015.

Chiodini, G., Selva, J., Del Pezzo, E., Marsan, D., De Siena, L., D’Auria, L., Bianco, F., Caliro, S., De Martino, P., Ricciolino, P., and Petrillo, Z.: Clues on the origin of post-2000 earthquakes at Campi Flegrei caldera (Italy), Sci. Rep., 7, 4472, https://doi.org/10.1038/s41598-017-04845-9, 2017.

Crocitti, M., Sulpizio, R., Insinga, D. D., De Rosa, R., Donato, P., Iorio, M., Zanchetta, G., Barca, D., and Lubritto, C.: On ash dispersal from moderately explosive volcanic eruptions: Examples from Holocene and Late Pleistocene eruptions of Italian volcanoes, J. Volcanol. Geoth. Res., https://doi.org/10.1016/j.jvolgeores.2018.07.009, in press, 2018.

D’Argenio, B., Angelino, A., Aiello, G., de Alteriis, G., Milia, A., Sacchi, M., Tonielli, R., Budillon, F., Chiocci, F., Conforti, A., De Lauro, M., Di Martino, G., D’Isanto, C., Esposito, E., Ferraro, L., Innangi, S., Insinga, D., Iorio, M., Marsella, E., Molisso, F., Morra, V., Passaro, S., Pelosi, N., Porfido, S., Raspini, A., Ruggieri, S., Sarnacchiaro, G., Terranova, C., Vilardo, G., and Violante, C.: Digital elevation model of the Naples bay and adjacent areas, eastern Tyrrhenian Sea, in: Mapping geology in Italy, edited by: Pasquaré, G., Venturini, C., and Groppelli, G., Rome APAT, Dipartimento Difesa del Suolo-Servizio Geologico d'Italia, 21-28, 2004.

Deino, A. L., Orsi, G., de Vita, S., and Piochi, M.: The age of the Neapolitan Yellow Tuff caldera-forming eruption (Campi Flegrei caldera, Italy) assessed by 40Ar/39Ar dating method, J. Volcanol. Geotherm. Res., 133, 157-170, 2004.

Del Gaudio, C., Aquino, I., Ricco, C., and Scandone, R.: Unrest episodes at Campi Flegrei: A reconstruction of vertical ground movements during 1905-2009, J. Volcanol. Geoth. Res., 195 , 48-56, https://doi.org/10.1016/j.jvolgeores.2010.05.014, 2010.

De Natale, G. and Troise, C.: The "Campi Flegrei Deep Drilling Project": From risk mitigation to renewable energy production, Eur. Rev., 19, 337-353, https://doi.org/10.1017/S1062798711000111, 2011.

De Natale, G. and Zollo A.: Statistical analysis and clustering features of the Phlegraean Fields earthquake sequence, May '83May '84, B. Seismol. Soc. Am., 76, 801-814, 1986.

De Natale, G., Pingue, F., Allard, P., and Zollo A.: Geophysical and geochemical modeling of the Campi Flegrei caldera, J. Volcanol. Geotherm. Res., 48, 199-222, 1991. 
De Natale, G., Zollo, A., Ferraro, A., and Virieux, J.: Accurate fault mechanism determinations for a 1984 earthquake swarm at Campi Flegrei caldera (Italy) during an unrest episode: implications for volcanological research, J. Geophys. Res., 100, $24167-$ 24185, 1995.

De Natale, G., Troise, C., and Pingue, F.: A mechanical fluiddynamical model for ground movements at Campi Flegrei caldera, J. Geodyn., 32, 487-517, 2001.

De Natale, G., Troise, C., Pingue, F., Mastrolorenzo, G., Pappalardo, L., Battaglia, M., and Boschi, E.: The Campi Flegrei Caldera: unrest mechanisms and hazards, in: Mechanisms of Activity and Unrest at Large Calderas, edited by: Troise, C., De Natale, G., and Kilburn, C. R. J., Geological Society, London, UK, Special Publications, 269, 25-45, 2006.

De Natale, G., Troise, C., Mark, D., Mormone, A., Piochi, M., Di Vito, M., A., Isaia, R., Carlino, S., Barra, D., and Somma, R.: The Campi Flegrei Deep Drilling Project (CFDDP): New insight on caldera structure, evolution and hazard implications for the Naples area (Southern Italy), Geochem. Geophy. Geosy., 17, 4836-4847, 2016.

De Vivo, B. and Lima, A.: A hydrothermal model for ground movements (bradyseism) at Campi Flegrei, Italy, in: Volcanism in the Campania Plain: Vesuvius, Campi Flegrei, Ignimbrites, edited by: De Vivo, B., Elsevier, Dev. Volcano., 9, 289-317, 2006.

De Vivo, B., Rolandi, G., Gans, P. B., Calvert, A., Bohrson, W. A., Spera, F. J., and Belkin, H. E.: New constraints on the pyroclastic eruptive history of the Campanian Volcanic Plain (Italy), Mineral. Petrol. 73, 47-65, 2001.

Di Donato, V., Insinga, D.D., Iorio, M., Molisso, F., Rumolo, P., Cardines, C., and Passaro, S.: The palaeoclimatic and palaeoceanographic history of the Gulf of Taranto (Mediterranean Sea) in the last $15 \mathrm{kyr}$, Global Planet. Change, 172, 278-297, 2019.

Di Luccio, F., Pino, N. A., Piscini, A., and Ventura, G.: Significance of the 1982-2014 Campi Flegrei seismicity: pre-existing structures, hydrothermal processes and hazard assessment, Geophys. Res. Lett., 42, 7498-7506, https://doi.org/10.1002/2015GL064962, 2015.

Di Vito, M. A., Isaia, R., Orsi, G., Southon, J., De Vita, S., D'antonio, M., Pappalardo, L., and Piochi, M.: Volcanism and deformation since 12,000 years at the Campi Flegrei Caldera (Italy), J. Volcanol. Geoth. Res., 91, 221-246, https://doi.org/10.1016/S0377-0273(99)00037-2, 1999.

Di Vito, M. A., Acocella, V., Aiello, G., Barra, D., Battaglia, M., Carandente, A., Del Gaudio, C., De Vita, S., Ricciardi, G. P., Ricco, C., Scandone, R., and Terrasi, F.: Magma transfer at Campi Flegrei caldera (Italy) before the 1538 AD eruption, Sci. Rep., 6, 1-9, https://doi.org/10.1038/srep32245, 2016.

Druitt, T. H. and Sparks, R. S. J.: On the formation of calderas during ignimbrite eruptions, Nature, 310, 679-681, 1984.

Dvorak, J. and Berrino, G.: Recent ground movement and seismic activity in Campi Flegrei, southern Italy, episodic growth of a resurgent dome, J. Geophys. Res., 96, 2309-2323, 1991.

Elders, A., Friðleifsson, G. Ó., Zierenberg, R. A., Pope, E. C., Mortensen, A. K., Guðmundsson, Á., Lowenstern, J. B., Marks, N. E., Owens, L., Bird, D. K., Reed, M., Olsen, N. J., and Schiffman, P.: Origin of a rhyolite that intruded a geothermal well while drilling at the Krafla volcano, Iceland, Geology, 39, 231-234, 2011.
Ferranti, L., Oldow, J. S., and Sacchi, M.: Pre-Quaternary orogenparallel extension in the Southern Apennine belt, Italy, Tectonophysics, 260, 325-347, 1996.

Fitzsimmons, K. E., Hambach, U., Veres, D., and Iovita R.: The Campanian Ignimbrite Eruption: New Data on Volcanic Ash Dispersal and Its Potential Impact on Human Evolution, PLoS ONE, 8, e65839, https://doi.org/10.1371/journal.pone.0065839, 2013.

Folch, A. and Martí, J.: Geometrical and mechanical constraints on the formation of ring-fault calderas, Earth Planet. Sc. Lett., 22, 215-225, 2004.

Geyer, A., Folch, A., and Martì, J.: Relationship between caldera collapse and magma chamber withdrawal: An experimental approach, J. Volcanol. Geotherm. Res., 157, 375-386, 2006.

Giaccio, B., Isaia, R., Fedele, F., Canzio, E., Hoffecker, J., Ronchitelli, A., Sinitsyn, A., Anikovich, M., Lisitsyn, S., and Popov, V.: The Campanian Ignimbrite and Codola tephra layers: Two temporal/stratigraphic markers for the Early Upper Palaeolithic in southern Italy and eastern Europe, J. Volcanol. Geoth. Res., 177, 208-226, 2008.

Giaccio, B., Hajdas, I., Isaia, R., Deino, A., and Nomade, S.: High-precision $14 \mathrm{C}$ and $40 \mathrm{Ar} / 39 \mathrm{Ar}$ dating of the Campanian Ignimbrite (Y-5) reconciles the time-scales of climatic-cultural processes at $40 \mathrm{ka}$, Sci. Rep., 7, 45940, https://doi.org/10.1038/srep45940, 2017.

Gregg, P. M., de Silva, S. L., Grosfils, E. B., and Parmigiani, J. P.: Catastrophic Caldera Collapse: Models implementing temperature-dependant rheology, J. Volcanol. Geoth. Res., 241242, 1-12, https://doi.org/10.1016/j.jvolgeores.2012.06.009, 2012.

Gregg, P. M., de Silva, S. L., and Grosfils, E. B.: Thermomechanics of shallow magma chamber pressurization: Implications for the assessment of ground deformation data at active volcanoes, Earth Planet. Sc. Lett., 384, 100-108, https://doi.org/10.1016/j.epsl.2013.09.040, 2013.

Gudmundsson, A.: Formation and development of normal-fault calderas and the initiation of large explosive eruptions, B. Volcanol., 60, 160-170, 1998.

Gudmundsson, M. T., Sigmundsson, F., and Björnsson, H.: Icevolcano interaction of the 1996 Gjálp subglacial eruption, Vatnajökull, Iceland, Nature, 389, 954-957, 1997.

Homuth, S., Pálsson, B., Holmgeirsson, S., and Sass, I.: Risk Management and Contingency Planning for the First Icelandic Deep Drilling Project Well in Krafla, Iceland, Proceedings World Geothermal Congress, 25-29 April 2010, Bali, Indonesia, 1-12, 2010.

Insinga, D. D., Tamburrino, S., Lirer, F., Vezzoli, L., Barra, M., De Lange, G. L., Tiepolo, M., Vallefuoco, M., Mazzola, S., and Sprovieri, M.: Tephrocronology of the astronomically-tuned KC01B deep-sea core, Ionian Sea insights into the explosive activity of the Central Mediterranean during the last $200 \mathrm{ka}$, Quaternary Sci. Rev., 85, 63-84, 2014.

Kilburn, C. R. J., De Natale, G., and Carlino, S.: Progressive approach to eruption at Campi Flegrei caldera in southern Italy, Nat. Commun., 8, 15312, https://doi.org/10.1038/ncomms15312, 2017.

Lavallee, Y., Stix, J., Kennedy, B., Richer, M., and Longpré, M.A.: Caldera subsidence in areas of variable topographic relief: Results from analogue modelling, J. Volcanol. Geotherm. Res., 129, 219-236, 2004. 
Lima, A., De Vivo, B., Spera, F. J., Bodnar, R. J., Milia, A., Nunziata. C., Belkin, H. E., and Cannatelli. C.: Thermodynamic model for uplift and deflation episodes (bradyseism) associated with magmatic: Hydrothermal activity at the Campi Flegrei (Italy), Earth Sci. Rev., 97, 44-58, 2009.

Lipman, P. W.: Calderas, in: Encyclopedia of Volcanoes, edited by: Sigurdsson, H., Academic Press, San Diego, USA, 643-662, 2000.

Lowenstern, J. B., Sisson, T. W., and Hurwitz, S.: Probing magma reservoirs to improve volcano forecasts, Eos, 98, https://doi.org/10.1029/2017EO085189, 2017.

Martí, J. and Gudmundsson, A.: The Las Cañadas caldera (Tenerife, Canary Islands): an overlapping collapse calderas generated by magma chamber migration, J. Volcanol. Geoth. Res., 103, 161173,2000

Martí, J., Mitjavila, J., and Araña,V.: Stratigraphy, structure and geochronology of the Las Cañadas caldera (Tenerife, Canary Islands), Geol. Mag., 131, 715-727, 1994.

Martí, J., Geyer, A., Folch, A., and Gottsmann, J.: A review on collapse calderas modeling, in: Caldera Volcanism: Analysis, Modelling and Response. Developments in Volcanology, edited by: Gottsmann, J. and Martí, J., Elsevier B. V, Amsterdam, the Netherlands, 10, 233-283, 2008.

Mastrolorenzo, G., Papparlardo, L., Troise, C., Rossano, S., Panizza, A., and De Natale, G.: Volcanic hazard assessment at Campi Flegrei Caldera, in: Mechanisms of Activity and Unrest at Large Calderas, edited by: Troise, C., De Natale, G., and Kilburn, C. R. J., Geological Society, London, UK, Special Publications, 269, 159-172, 2006.

Mastrolorenzo, G., Pappalardo L., Troise, C., Panizza A., and De Natale, G.: Probabilistic tephra fall-out hazard maps in Neapolitan area from quantitative volcanological study of Campi Flegrei eruptions, J. Geophys. Res., 113, B07203, https://doi.org/10.1029/2007JB004954, 2008.

Milia, A. and Torrente, M. M.: Tectonics and stratigraphic architecture of a peri-Tyrrhenian halfgraben (Bay of Naples, Italy), Tectonophysics, 315, 297-314, 1999.

Milia, A. and Torrente, M. M.: The influence of paleogeographic setting and crustal subsidence on the architecture of ignimbrites in the Bay of Naples (Italy), Earth Planet. Sc. Lett., 263, 192206, 2007.

Moretti, R., De Natale, G., and Troise, C.: A geochemical and geophysical reappraisal to the significance of the recent unrest at Campi Flegrei caldera (Southern Italy), Geochem. Geophy. Geosy., 18, 1244-1269, https://doi.org/10.1002/2016GC006569, 2017.

Moretti, R., Troise, C., Sarno, F., and De Natale, G.: Caldera unrest driven by $\mathrm{CO}_{2}$-induced drying of the deep hydrothermal system, Sci. Rep., 8, 8309, https://doi.org/10.1038/s41598-018-26610-2, 2018.

Nakada, S.: Scientific Results of Volcano Drilling and Future Prospects, J. Geogr., 122, 258-272, 2013.

Newhall, C. G. and Dzurisin, D.: Historical Unrest at Large Calderas of the World: U.S. Geological Survey Bulletin 1855, U.S. Government Printing Office, Washington, USA, 1108 pp., 1988.

Oldow, J. S., D’Argenio, B., Ferranti, L., Pappone, G., Marsella, E., and Sacchi, M.: Large-scale longitudinal extension in the south- ern Apennines contractional belt, Italy, Geology, 21, 1123-1126, 1993.

Orsi, G., De Vita, S., and di Vito, M.: The restless, resurgent Campi Flegrei nested caldera (Italy): Constraints on its evolution and configuration, J. Volcanol. Geotherm. Res., 74, 179-214, 1996.

Passaro, S., Genovese, S., Sacchi, M., Barra, M., Rumolo, P., Tamburrino S., Mazzola, S., Basilone, G., Placenti, F., Aroica, S., and Bonanno, A.: First hydroacoustic evidence of marine, active fluid vents in the Naples Bay continental shelf (Southern Italy), J. Volcanol. Geoth. Res., 285, 29-35, 2014.

Passaro, S., Tamburrino, S., Vallefuoco, M., Tassi, F., Vaselli, O., Giannini, L., Chiodini, G., Caliro, S., Sacchi, M., Rizzo, A. L., and Ventura, G.: Seafloor doming driven by degassing processes unveils sprouting volcanism in coastal areas, Sci. Rep., 6, 22448, https://doi.org/10.1038/srep22448, 2016.

Pyle, D., Ricketts, G., Margari, V., Andel, T., Sinitsyn, A., Praslov, N., and Lisitsyn, S.: Wide dispersal and deposition of distal tephra during the Pleistocene "Campanian Ignimbrite/Y5" eruption, Italy, Quaternary Sci. Rev., 25, 2713 2728, https://doi.org/10.1016/j.quascirev.2006.06.008, 2006.

Roche, O. and Druitt, T. H.: Onset of caldera collapse during ignimbrite eruptions, Earth Planet. Sc. Lett., 191, 191-202, 2001.

Roche, O., Druitt, T. H., and Merle, O.: Experimental study of caldera formation, J. Geophys. Res., 105B, 395-416, 2000.

Rolandi, G., Bellucci, F., Heizler, M., Belkin, H. E., and De Vivo, B.: Tectonic controls on the genesis of ignimbrites from the Campanian Volcanic Zone, southern Italy, Mineral. Petrol., 79, 3-31, 2003.

Rosi, M. and Sbrana, A.: Phlegrean Fields, CNR, Quaderni de "La Ricerca Scientifica”, 176, 114-119, 1987.

Rossano, S., Mastrolorenzo G., and De Natale G.: Numerical simulation of pyroclastic density currents on Campi Flegrei topography: a tool for statistical hazard estimation, J. Volcanol. Geoth. Res., 132, 1-14, 2004.

Sacchi, M., Alessio, G., Aquino, I., Esposito, E., Molisso, F., Nappi, R., Porfido, S., and Violante, C.: Risultati preliminari della campagna oceanografica CAFE_07 - Leg 3 nei Golfi di Napoli e Pozzuoli, Mar Tirreno Orientale, Quaderni di Geofisica, 64, 3 26, 2009.

Sacchi, M., Pepe, F., Corradino, M., Insinga, D. D., Molisso, F., and Lubritto, C.: The Neapolitan Yellow Tuff caldera offshore the Campi Flegrei: Stratal architecture and kinematic reconstruction during the last $15 \mathrm{kyr}$, Mar. Geol., 354, 15-33, 2014.

Saito, S., Sakuma, S., and Uchida, T., Frontier geothermal drilling operations succeeded at $500^{\circ} \mathrm{C}$ BHST, SPE/LADC Drilling Conference 37625, 4-6 March 1997, Amsterdam, the Netherlands, Society of Petroleum Engineers, https://doi.org/10.2118/37625MS, 1997.

Sandri, L., Costa, A., Selva, J., Tonini, R., Macedonio, G., Folch, A., and Sulpizio, R.: Beyond eruptive scenarios: assessing tephra fallout hazard from Neapolitan volcanoes, Sci. Rep., 6, 24271, https://doi.org/10.1038/srep24271, 2016.

Sandri, L., Tierz, P., Costa, A., and Marzocchi, W.: Probabilistic hazard from pyroclastic density currents in the Neapolitan area (Southern Italy), J. Geophys. Res.-Sol. Ea., 123, 3474-3500, 2018.

Sawolo, N., Sutriono, E., Istadi, B. P., and Darmoyo, A. B.: The LUSI mud volcano triggering controversy: Was it caused 
by drilling?, Marine and Petroleum Geology, 26, 1766-1784, https://doi.org/10.1016/j.marpetgeo.2009.04.002, 2009.

Scarpati, C., Cole, P., and Perrotta, A.: The Neapolitan Yellow Tuff - A large volume multiphase eruption from Campi Flegrei, Southern Italy, B. Volcanol., 55, 343-356, 1993.

Somma, R., Iuliano, S., Matano, F., Molisso, F., Passaro, S., Sacchi, M., Troise, C., and De Natale, G.: High-resolution morphobathymetry of Pozzuoli Bay, southern Italy, J. Maps, 12, 222230, https://doi.org/10.1080/17445647.2014.1001800, 2016.

Steinmann, L., Spiess, V., and Sacchi, M.: The Campi Flegrei caldera (Italy): Formation and evolution in interplay with sealevel variations since the Campanian Ignimbrite eruption at 39 ka, J. Volcanol. Geoth. Res., 327, 361-374, 2016.

Steinmann, L., Spiess, V., and Sacchi, M.: Post-collapse evolution of a coastal caldera system: Insights from a 3D multichannel seismic survey from the Campi Flegrei caldera (Italy), J. Volcanol. Geoth. Res., 349, 83-98, 2018.

Sulpizio, R., Zanchetta, G., Caron, B., Dellino, P., Mele, D., Giaccio, B., Insinga, D., Paterne, M., Siani, G., Costa, A., Macedonio, G., and Santacroce, R.: Volcanic ash hazard in the Central Mediterranean assessed from geological data, B. Volcanol., 76, 866, https://doi.org/10.1007/s00445-014-0866-y, 2014.
Tonini, R., Sandri, L., Costa, A., and Selva, J.: Brief Communication: The effect of submerged vents on probabilistic hazard assessment for tephra fallout, Nat. Hazards Earth Syst. Sci., 15, 409-415, https://doi.org/10.5194/nhess-15-409-2015, 2015.

Troiano, A., Di Giuseppe, M. G., Petrillo, Z., Troise, C., and De Natale, G.: Ground deformation at calderas driven by fluid injection: Modelling unrest episodes at Campi Flegrei (Italy), Geophys J. Int., 187, 833-847, 2011.

Troise, C., De Natale, G., Pingue, F., Obrizzo, F., De Martino, P., Tammaro, U., and Boschi, E.: Renewed ground uplift at Campi Flegrei caldera (Italy): new insight on magmatic processes and forecast, Geophys. Res. Lett., 34, L03301, https://doi.org/10.1016/j.earscirev.2018.11.007, 2007.

Troise, C., De Natale, G., Schiavone, R., Somma, R., and Moretti, R.: The Campi Flegrei caldera unrest: Discriminating magma intrusions from hydrothermal effects and implications for possible evolution, Earth Sci. Rev, 188, 108-122, 2019. 